
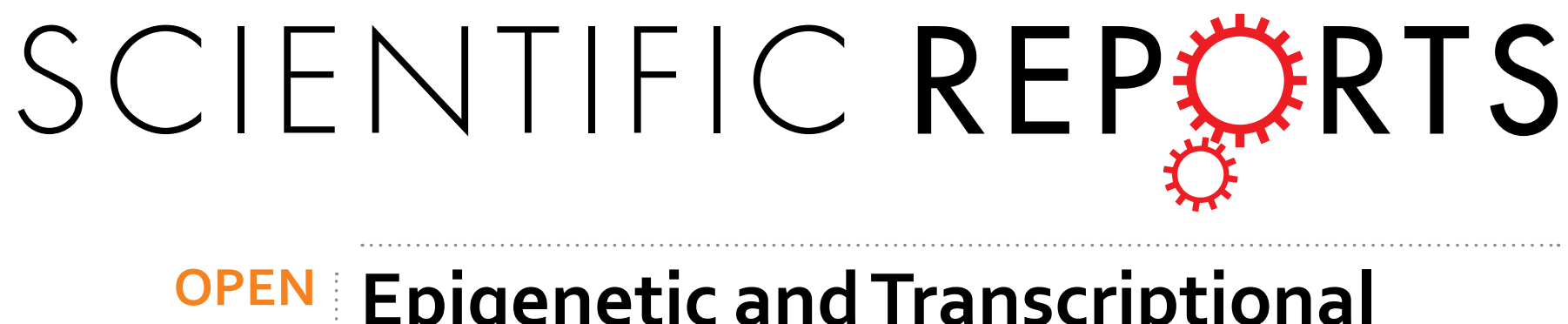

\title{
Epigenetic and Transcriptional Alterations in Human Adipose Tissue of Polycystic Ovary
}

Received: 15 September 2015

Accepted: 23 February 2016

Published: 15 March 2016

\section{Syndrome}

Milana Kokosar ${ }^{1}$, Anna Benrick ${ }^{1}$, Alexander Perfilyev ${ }^{2}$, Romina Fornes ${ }^{3}$, Emma Nilsson ${ }^{2}$, Manuel Maliqueo ${ }^{3,4}$, Carl Johan Behre ${ }^{5}$, Antonina Sazonova ${ }^{6}$, Claes Ohlsson ${ }^{7}$, Charlotte Ling ${ }^{2}$ \& Elisabet Stener-Victorin ${ }^{3}$

Genetic and epigenetic factors may predispose women to polycystic ovary syndrome (PCOS), a common heritable disorder of unclear etiology. Here we investigated differences in genome-wide gene expression and DNA methylation in adipose tissue from 64 women with PCOS and 30 controls. In total, 1720 unique genes were differentially expressed $(O<0.05)$. Six out of twenty selected genes with largest expression difference (CYP1B1, GPT), genes linked to PCOS (RAB5B) or type 2 diabetes (PPARG, SVEP1), and methylation (DMAP1) were replicated in a separate case-control study. In total, 63,213 sites $(P<0.05)$ and 440 sites $(Q<0.15)$ were differently methylated. Thirty differentially expressed genes had corresponding changes in 33 different DNA methylation sites. Moreover, a total number of 1913 pairs of differentially expressed "gene-CpG" probes were significantly correlated after correction for multiple testing and corresponded with 349 unique genes. In conclusion, we identified a large number of genes and pathways that are affected in adipose tissue from women with PCOS. We also identified specific DNA methylation pathways that may affect mRNA expression. Together, these novel findings show that women with PCOS have multiple transcriptional and epigenetic changes in adipose tissue that are relevant for development of the disease.

Polycystic ovary syndrome (PCOS) is the most common endocrine and metabolic disorder in women, with a worldwide prevalence of $7-15 \%{ }^{1}$. The reproductive phenotype of PCOS includes hyperandrogenism, ovulatory disturbances, and polycystic ovarian morphology. The metabolic phenotype includes hyperinsulinemia with pancreatic $\beta$-cell dysfunction, insulin resistance, and obesity. These metabolic abnormalities often precede type 2 diabetes $(\mathrm{T} 2 \mathrm{D})^{2,3}$. Compensatory hyperinsulinemia stimulates androgen production and secretion by thecal cells and reduces the level of sex hormone binding globulin, which increases free androgens and further exacerbates PCOS symptoms ${ }^{2}$. Thus, there is a strong association between hyperinsulinemia and hyperandrogenemia that drives a specific vicious circle. Despite the detrimental effect of PCOS on women's health, the etiology is not well understood. Genetic and environmental factors have been implicated in its development, but studies examining the impact of epigenetics on PCOS remain scarce ${ }^{4-6}$.

The considerable overlap between the reproductive and metabolic features of PCOS implicates adipose tissue dysfunction as a key feature of the disease ${ }^{7-10}$. Importantly, both lean and obese women with PCOS have aberrant

${ }^{1}$ Department of Physiology, Institute of Neuroscience and Physiology, Sahlgrenska Academy, University of Gothenburg, Gothenburg, Sweden. ${ }^{2}$ Epigenetics and Diabetes, Department of Clinical Sciences, Lund University Diabetes Centre, Lund University, Clinical Research Centre, Malmö, Sweden. ${ }^{3}$ Department of Physiology and Pharmacology, Karolinska Institutet, Stockholm, Sweden. ${ }^{4}$ Endocrinology and Metabolism Laboratory, Department of Medicine, West division, University of Chile, Santiago, Chile. ${ }^{5}$ The Wallenberg Laboratory and Sahlgrenska Center for Cardiovascular and Metabolic Research, Institute of Medicine, Sahlgrenska Academy, University of Gothenburg, Gothenburg, Sweden. ${ }^{6}$ Department of Obstetrics and Gynecology, Reproductive Medicine, Institute of Clinical Sciences, Sahlgrenska Academy, University of Gothenburg, Gothenburg, Sweden. ${ }^{7}$ Department of Internal Medicine, Centre for Bone and Arthritis Research, Institute of Medicine, Sahlgrenska Academy, University of Gothenburg, Gothenburg, Sweden. Correspondence and requests for materials should be addressed to E.S.-V. (email: elisabet. stener-victorin@ki.se) 
adipose tissue morphology and function, as evidenced by enlarged subcutaneous adipocytes and decreased secretion of adiponectin - two factors that are strongly associated with insulin resistance ${ }^{9}$. Further, subcutaneous adipocytes from women with PCOS are resistant to insulin-stimulated glucose uptake and display inhibited lipolysis ${ }^{11,12}$. Moreover, altered adipose tissue expression of genes such as PPARG, LEPR, TWIST1, CCL2 that may be important in PCOS pathophysiology have been identified ${ }^{13-18}$. These findings indicate that adipose tissue dysfunction may contribute to the pathogenesis of PCOS including insulin resistance and hyperandrogenism.

Emerging evidence from women with PCOS and from prenatally androgenized animal models suggests that maternal androgen excess predisposes offspring to $\mathrm{PCOS}^{19}$. An unfavorable intrauterine environment may lead to epigenetic changes that alter gene expression and increase risk of disease in adulthood ${ }^{20}$. Several lines of evidence support a role for epigenetic mechanisms in metabolic disturbances. For example, differential DNA-methylation in adipose tissue from subjects with T2D is associated with differential expression of genes involved in oxidative phosphorylation, mitochondrial function, and the metabolism of carbohydrates, amino acids, and lipids, all of which are relevant to the development of disease ${ }^{21}$. The possibility of an epigenetic component of PCOS was only recently explored ${ }^{4-6}$. Although hampered by minimal sample size ${ }^{22,23}$, these studies revealed differential DNA methylation and gene expression profiles in ovarian tissue within pathways related to the pathogenesis of PCOS. Also, epigenetic modification of PPARGC1A has been reported in granulosa cells from women with PCOS ${ }^{24}$.

Nevertheless, knowledge concerning the role of epigenetics in PCOS is limited. The genome-wide DNA methylation pattern has not been explored in human adipose tissue from women with and without PCOS, and genome-wide expression profiles have not been linked to the epigenome until just recently ${ }^{25}$. Therefore, our aim was to investigate genome-wide gene differences in expression and DNA methylation patterns in adipose tissue from 64 women with PCOS and 30 controls. In a separate case-control study, key findings were replicated in adipose tissue from 42 unrelated women.

\section{Results}

Clinical Characteristics. The characteristics of women in the two cohorts are presented in Table 1. In cohort 1 , women with PCOS were older $(30.0 \pm 4.4$ vs $27.6 \pm 3.54)$ and had a higher BMI. (28.4 \pm 7.1 vs $24.8 \pm 5.0)$ Therefore, all analyzes in cohort 1 were adjusted for age and BMI including clinical characteristics, genome-wide gene expression and methylation. Women with PCOS had a higher HOMA-IR (homeostatic model assessment of insulin resistance) and higher levels of $\mathrm{HbAlc}$ and circulating testosterone than controls, and a lower glucose disposal rate (GDR) as measured by euglycemic hyperinsulinemic clamp. In cohort 2 replication was performed in cases and controls that were overweight or obese and matched for age ( \pm 5 years), weight ( \pm 4 kilogram), and body mass index (BMI) $( \pm 2)$ with controls. Women with PCOS in cohort 2 had higher HOMA-B (reflecting insulin secretion) and circulating testosterone levels and larger adipocytes than controls (Table 1).

Phenotypic presentation. In cohort 1, 49 of the 64 women with PCOS met all three criteria for PCOS: hyperandrogenism, irregular cycles, and PCO morphology; 15 had hyperandrogenemia and PCO morphology. In cohort 2, 13 of the 21 women with PCOS met all three PCOS criteria; two had hyperandrogenemia and PCO morphology, one had hyperandrogenemia and irregular cycles, and five had irregular cycles and PCO morphology.

Differential expression in adipose tissue. To investigate differential gene expression in adipose tissue, we used Illumina HumanHT-12 v4 Expression BeadChips to analyze subcutaneous adipose tissue from the 64 women with PCOS and the 30 controls in cohort 1 . Each chip has 47,000 probes that represent well-characterized genes and unknown splice variants. A false-discovery rate (FDR) $<5 \%(Q<0.05)$ was used to correct for multiple testing. After correction, 1899 probe sets, representing 1769 annotated transcripts and 1720 unique genes $(Q<0.05)$, were differentially expressed in adipose tissue from women with PCOS and controls (Table S1). Of the 1720 unique genes, 912 were down-regulated (by up to 57\%) and 808 were up-regulated (by up to 58\%) in women with PCOS (Table S1).

Next, all differentially expressed genes $(P<0.05)$ were analyzed with Ingenuity Pathway Analysis software to identify biological canonical pathways. All significantly up- and down-regulated gene sets are presented in Table 2. A selection of significantly up- and down-regulated canonical pathways relevant to PCOS and T2DPI3K/AKT, ERK/MAPK-, androgen, TGF- $\beta$, IGF-1, NGF, telomerase, and NRF2-mediated oxidative stress response signaling pathways-are shown in Fig. 1A-H. All genes contributing to significantly up-regulated and down-regulated canonical pathways are presented in Tables S2 and S3, respectively.

Fifty genes whose expression in adipose tissue differed the most between women with PCOS and controls $(Q<0.05)$ are presented in Table 3. Among the most up-regulated genes (expression range $34.8 \%$ to $57.8 \%$ ) we found genes associated with hormone/aromatase activity and metabolic disturbances (e.g., CD74, APOLD1, $C Y P 1 B 1$, and UCP2). Among the most down-regulated genes (expression range $-28.7 \%$ to $-57.4 \%$ ) were those involved in metabolic disturbance, including T2D, glycerol and lipid processes (e.g., SLC7A10, UGP2 and GPT).

Next we investigated whether genes linked to PCOS, T2D, and obesity in published GWAS $\left(P<5 \times 10^{5}\right.$; http:// www.ebi.ac.uk/gwas, accessed on August 20,2015) were differently expressed in adipose tissue from women with PCOS versus controls $(Q<0.05)$. We found one out of nineteen PCOS candidate genes, $R A B 5 B^{26}$, expressed at a lower level in adipose tissue from women with PCOS (Table 4). Additionally, 18 out of 597 T2D candidate genes (e.g., $P P A R G^{27}, S V E P 1^{28}$, and $I R S 1^{29}$ ) and five out of 1238 obesity candidate genes (e.g. $R T N 4^{30}$ and $L E P R^{31}$ ) were differentially expressed in adipose tissue from women with PCOS (Table 4).

Replication of differential mRNA expression. We proceeded to replicate differential gene expression in cohort 2. Selected differentially expressed genes were (1) among those with largest fold change e.g.: CYP1B1 $1^{32}$, which was up-regulated and is involved in metabolism of sex steroids and adipogenesis, and GPT ${ }^{33}$, which was down-regulated and is involved in glucose and amino acid metabolism; (2) among candidate genes identified in 


\begin{tabular}{|c|c|c|c|}
\hline Cohort 1 & Controls $(\mathrm{n}=30)$ & $\operatorname{PCOS}(n=64)$ & $P_{\text {value }}$ \\
\hline Age (years) & $27.6 \pm 3.54$ & $30.0 \pm 4.4$ & $\mathrm{NA}$ \\
\hline \multicolumn{4}{|l|}{ Anthropometry } \\
\hline BMI $\left(\mathrm{kg} / \mathrm{m}^{2}\right)$ & $24.8 \pm 5.0$ & $28.4 \pm 7.1$ & $\mathrm{NA}$ \\
\hline Waist-to-Hip-Ratio & $0.79 \pm 0.06$ & $0.84 \pm 0.07$ & 0.027 \\
\hline \multicolumn{4}{|c|}{ PCOS characteristics, n (\%) } \\
\hline Oligo/amenorrhea & 0 & $76 \%(55)$ & NA \\
\hline Hirsutism & 0 & $75 \%(54)$ & NA \\
\hline Acne (yes/no) & 0 & $64 \%(46)$ & NA \\
\hline \multicolumn{4}{|l|}{ Hormones } \\
\hline Estradiol (pg/ml) & $38.9 \pm 18.2$ & $73.9 \pm 40.3$ & $<0.000$ \\
\hline Testosterone $(\mathrm{ng} / \mathrm{ml})$ & $0.21 \pm 0.08$ & $0.45 \pm 0.18$ & $<0.000$ \\
\hline SHBG (nmol/l) & $67.8 \pm 29.6$ & $39.3 \pm 21.3$ & $<0.000$ \\
\hline \multicolumn{4}{|l|}{ Metabolic measures } \\
\hline HOMA-IR & $1.22 \pm 0.82$ & $2.48 \pm 2.16$ & 0.008 \\
\hline HOMA-B & $152.5 \pm 113.2$ & $203.3 \pm 159.6$ & 0.522 \\
\hline GDR (mg/kg x min) & $12.58 \pm 3.45$ & $9.69 \pm 3.16$ & 0.005 \\
\hline Hbalc $(\mathrm{mmol} / \mathrm{mol})$ & $28.73 \pm 5.94$ & $31.56 \pm 3.07$ & 0.016 \\
\hline Adipocyte size $(\mu \mathrm{m})$ & $93.2 \pm 9.87$ & $100.2 \pm 11.45$ & 0.153 \\
\hline Cohort 2 & Controls $(n=21)$ & $\operatorname{PCOS}(n=21)$ & $P$ value $^{\mathrm{b}}$ \\
\hline Age (years) & $29.8 \pm 6.4$ & $31.2 \pm 5.6$ & 0.520 \\
\hline \multicolumn{4}{|l|}{ Anthropometry } \\
\hline BMI $\left(\mathrm{kg} / \mathrm{m}^{2}\right)$ & $30.4 \pm 3.62$ & $31.2 \pm 4.12$ & 0.534 \\
\hline Waist-to-Hip-Ratio & $0.82 \pm 0.05$ & $0.85 \pm 0.08$ & 0.155 \\
\hline \multicolumn{4}{|c|}{ PCOS characteristics, n (\%) } \\
\hline Oligo/amenorrhea & 0 & $85 \%(18)$ & NA \\
\hline Hirsutism & 0 & $67 \%(14)$ & NA \\
\hline Acne (yes/no) & 0 & $43 \%(9)$ & $\mathrm{NA}$ \\
\hline \multicolumn{4}{|l|}{ Hormones } \\
\hline Estradiol (pg/ml) & $57.3 \pm 41.8$ & $87.12 \pm 63.2$ & 0.080 \\
\hline Testosterone $(\mathrm{ng} / \mathrm{ml})$ & $0.25 \pm 0.09$ & $0.49 \pm 0.30$ & $<0.001$ \\
\hline SHBG (nmol/l) & $39.5 \pm 25.0$ & $38.9 \pm 16.2$ & 0.819 \\
\hline \multicolumn{4}{|l|}{ Metabolic measures } \\
\hline HOMA-IR & $2.20 \pm 1.11$ & $3.18 \pm 2.05$ & 0.061 \\
\hline HOMA-B & $121.5 \pm 62.9$ & $196.9 \pm 132.7$ & 0.020 \\
\hline GDR (mg/kg x min) & $6.73 \pm 2.84$ & $6.17 \pm 3.11$ & 0.549 \\
\hline Hbalc $(\mathrm{mmol} / \mathrm{mol})$ & $31.8 \pm 2.91$ & $31.6 \pm 2.55$ & 0.911 \\
\hline Adipocyte size $(\mu \mathrm{m})$ & $110.5 \pm 8.03$ & $116.7 \pm 9.78$ & 0.030 \\
\hline
\end{tabular}

Table 1. Clinical characteristics of women with polycystic ovary syndrome and controls in cohorts 1 and 2. Values are mean \pm standard deviation (SD). BMI, body mass index; SHBG, sex hormone binding globulin; LH, luteinizing hormone; FSH, follicle-stimulating hormone; HOMA, homeostatic model assessment; GDR, glucose

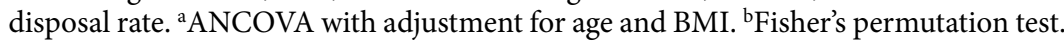

GWAS studies of $\mathrm{PCOS}^{26}$ (RAB5B, involved in regulation of intracellular vesicle transport), T2D ${ }^{27-29}$ (PPARG, $S V E P 1$, and $I R S 1$, involved in fatty acid storage and glucose metabolism), and obesity ${ }^{30}$ (RTN4, a multifunctional gene linked to extreme obesity); and (3) among genes with overlapping with methylation (DMAP1), which is involved in DNA methylation and regulation of obesity-related inflammation and cancer ${ }^{34}$, all with a $Q<0.05$ (Fig. 2A, Table S4).

Six of the 20 selected genes were successfully replicated in cohort 2 , as shown by significant expression differences in the same direction as in cohort 1 (Fig. 2B, Table S4). The mRNA expression of CYP1B1 was higher and the mRNA expression of GPT, RAB5B, PPARG, SVEP1, and DMAP1 was significantly lower in adipose tissue of women with PCOS. IRS1 and RTN4 were differentially expressed but in directions opposite to those in cohort 1 . The expression of $C D 74$, the gene with the largest increase in expression in cohort 1, was upregulated in cohort 2, although not significant $(P=0.061)$, and the expression of $A D I P O R 2$ was down regulated $(P=0.069)$ (Table S4).

Next we preformed western blot (WB) analyses as protein expression is more relevant for biological functions. Protein expression of CYP1B1 was higher in adipose tissue of women with PCOS compared with controls (Fig. 2C) reflecting differential gene expression obtained from BeadChip gene expression array and in the replication cohort 2 (Fig. 2A,B). Protein expression of PPARG displayed a week trend to be lower (Fig. 2D). The WB analyses are hampered by small sample size and big variations. 


\begin{tabular}{|c|c|c|c|c|c|c|}
\hline Pathway & Regulated/total & Ratio & Z-score & $P$ value & Signaling Pathway Category & Top Function \& Diseases \\
\hline \multicolumn{7}{|l|}{ Up-regulated pathways } \\
\hline PI3K/AKT Signaling & $25 / 113$ & 0.221 & 2.132 & $1.72 \mathrm{E}-5$ & $\begin{array}{l}\text { Cancer; Cellular Growth, Proliferation and } \\
\text { Development; Intracellular and Second Messenger } \\
\text { Signaling }\end{array}$ & Cell Death and Survival; Cancer; Cell Cycle \\
\hline ILK Signaling & $28 / 152$ & 0.184 & 2.887 & $1.79 \mathrm{E}-4$ & Cellular Growth, Proliferation and Development & $\begin{array}{l}\text { Cellular Movement; Cancer; Cardiovascular System } \\
\text { Development and Function }\end{array}$ \\
\hline ERK/MAPK Signaling & $29 / 167$ & 0.174 & 1.347 & $3.92 \mathrm{E}-4$ & Cancer; Intracellular and Second Messenger Signaling & $\begin{array}{l}\text { Cancer; DNA Replication, Recombination, and Repair; } \\
\text { Cell Cycle }\end{array}$ \\
\hline $\begin{array}{l}\text { Cholecystokinin/Gastrin- } \\
\text { mediated Signaling }\end{array}$ & $19 / 93$ & 0.204 & 4.359 & $5.03 \mathrm{E}-4$ & $\begin{array}{l}\text { Neurotransmitters and Other Nervous System } \\
\text { Signaling }\end{array}$ & $\begin{array}{l}\text { DNA Replication, Recombination, and Repair; } \\
\text { Developmental Disorder; Cellular Development }\end{array}$ \\
\hline ERK5 Signaling & $14 / 62$ & 0.226 & 3.162 & $9.60 \mathrm{E}-4$ & Intracellular and Second Messenger Signaling & $\begin{array}{l}\text { DNA Replication, Recombination, and Repair; Cancer; } \\
\text { Developmental Disorder }\end{array}$ \\
\hline p70S6K Signaling & $20 / 107$ & 0.187 & 1.698 & $1.18 \mathrm{E}-3$ & $\begin{array}{l}\text { Cellular Growth, Proliferation and Development; } \\
\text { Cellular Stress and Injury }\end{array}$ & $\begin{array}{l}\text { Cellular Function and Maintenance; Cell Death and } \\
\text { Survival; Post-Translational Modification }\end{array}$ \\
\hline $\begin{array}{l}\text { Role of NFAT in Cardiac } \\
\text { Hypertrophy }\end{array}$ & $26 / 160$ & 0.163 & 3.545 & $2.06 \mathrm{E}-3$ & Cardiovascular Signaling; Disease-Specific Pathways & $\begin{array}{l}\text { Cardiac Hypertrophy; Cardiovascular Disease; } \\
\text { Developmental Disorder }\end{array}$ \\
\hline $\begin{array}{l}\text { Cardiac Hypertrophy } \\
\text { Signaling }\end{array}$ & $29 / 191$ & 0.152 & 4.707 & $3.35 \mathrm{E}-3$ & Cardiovascular Signaling; Disease-Specific Pathways & $\begin{array}{l}\text { Cardiac Hypertrophy; Cardiovascular Disease; } \\
\text { Developmental Disorder }\end{array}$ \\
\hline Androgen Signaling & $18 / 103$ & 0.175 & 2.333 & $4.35 \mathrm{E}-3$ & Nuclear Receptor Signaling & $\begin{array}{l}\text { ene Expression; Cell Death and Survival; Cellular } \\
\text { Development }\end{array}$ \\
\hline TGF- $\beta$-Signaling & $15 / 80$ & 0.188 & 1.508 & $4.51 \mathrm{E}-3$ & $\begin{array}{l}\text { Cellular Growth, Proliferation and Development; } \\
\text { Growth Factor Signaling; Ingenuity Toxicity List } \\
\text { Pathways }\end{array}$ & $\begin{array}{l}\text { Gene Expression; Embryonic Development; } \\
\text { Organismal Development }\end{array}$ \\
\hline IGF-1 Signaling & $16 / 92$ & 0.174 & 2.53 & $7.27 \mathrm{E}-3$ & $\begin{array}{l}\text { Cellular Growth, Proliferation and Development; } \\
\text { Growth Factor Signaling }\end{array}$ & $\begin{array}{l}\text { Cancer; Cellular Development; Hematological System } \\
\text { Development and Function }\end{array}$ \\
\hline VEGF Signaling & $15 / 85$ & 0.176 & 3.606 & $8.03 \mathrm{E}-3$ & $\begin{array}{l}\text { Cellular Growth, Proliferation and Development; } \\
\text { Growth Factor Signaling }\end{array}$ & $\begin{array}{l}\text { Cardiovascular System Development and Function; } \\
\text { Cell Cycle; Cell Death and Survival }\end{array}$ \\
\hline Phospholipase C Signaling & $29 / 207$ & 0.14 & 4.69 & $1.04 \mathrm{E}-2$ & Intracellular and Second Messenger Signaling & $\begin{array}{l}\text { Cell Signaling; Molecular Transport; Vitamin and } \\
\text { Mineral Metabolism }\end{array}$ \\
\hline $\begin{array}{l}\text { Acute Myeloid Leukemia } \\
\text { Signaling }\end{array}$ & $13 / 72$ & 0.181 & 3.051 & $1.08 \mathrm{E}-2$ & Cancer; Disease-Specific Pathways & $\begin{array}{l}\text { Cellular Development; Cellular Growth and } \\
\text { Proliferation; Hematological System Development and } \\
\text { Function }\end{array}$ \\
\hline $\begin{array}{l}\text { Cardiac } \beta \text {-adrenergic } \\
\text { Signaling }\end{array}$ & $18 / 113$ & 0.159 & 0.302 & $1.14 \mathrm{E}-2$ & Cardiovascular Signaling & $\begin{array}{l}\text { Skeletal and Muscular System Development and } \\
\text { Function; DNA Replication, Recombination, and } \\
\text { Repair; Molecular Transport }\end{array}$ \\
\hline NGF Signaling & $17 / 105$ & 0.162 & 4.123 & $1.18 \mathrm{E}-2$ & $\begin{array}{l}\text { Growth Factor Signaling; Neurotransmitters and } \\
\text { Other Nervous System Signaling }\end{array}$ & $\begin{array}{l}\text { Cancer; Cellular Growth and Proliferation; Cellular } \\
\text { Development }\end{array}$ \\
\hline Goq Signaling & $20 / 131$ & 0.153 & 4.243 & $1.26 \mathrm{E}-2$ & Intracellular and Second Messenger Signaling & $\begin{array}{l}\text { Post-Translational Modification; Lipid Metabolism; } \\
\text { Small Molecule Biochemistry }\end{array}$ \\
\hline Integrin Signaling & $25 / 175$ & 0.143 & 4.379 & $1.31 \mathrm{E}-2$ & $\begin{array}{l}\text { Cell Cycle Regulation; Cellular Growth, Proliferation } \\
\text { and Development; Intracellular and Second } \\
\text { Messenger Signaling }\end{array}$ & $\begin{array}{l}\text { Cell Morphology; Cellular Assembly and Organization; } \\
\text { Cellular Function and Maintenance }\end{array}$ \\
\hline AMPK Signaling & $20 / 133$ & 0.15 & 0.832 & $1.47 \mathrm{E}-2$ & $\begin{array}{l}\text { Cellular Growth, Proliferation and Development; } \\
\text { Intracellular and Second Messenger Signaling }\end{array}$ & $\begin{array}{l}\text { Energy Production; Lipid Metabolism; Small Molecule } \\
\text { Biochemistry }\end{array}$ \\
\hline Telomerase Signaling & $15 / 91$ & 0.165 & 1.155 & $1.48 \mathrm{E}-2$ & Apoptosis; Cancer & $\begin{array}{l}\text { Cellular Assembly and Organization; Cellular Function } \\
\text { and Maintenance; Cancer }\end{array}$ \\
\hline Ceramide Signaling & $13 / 75$ & 0.173 & 2.496 & $1.51 \mathrm{E}-2$ & Apoptosis; Cell Cycle Regulation & $\begin{array}{l}\text { Cell Death and Survival; Cell Signaling; Renal Necrosis/ } \\
\text { Cell Death }\end{array}$ \\
\hline mTOR Signaling & $24 / 170$ & 0.141 & 2.183 & $1.70 \mathrm{E}-2$ & Cellular Growth, Proliferation and Development & $\begin{array}{l}\text { Cell Morphology; Protein Synthesis; Cellular Function } \\
\text { and Maintenance }\end{array}$ \\
\hline $\begin{array}{l}\text { fMLP Signaling in } \\
\text { Neutrophils }\end{array}$ & $16 / 102$ & 0.157 & 3.742 & $1.89 \mathrm{E}-2$ & Cellular Immune Response; Cytokine Signaling & $\begin{array}{l}\text { Cell-To-Cell Signaling and Interaction; Cellular } \\
\text { Function and Maintenance; Inflammatory Response }\end{array}$ \\
\hline CXCR4 Signaling & $19 / 128$ & 0.148 & 4 & $1.94 \mathrm{E}-2$ & Cellular Immune Response; Cytokine Signaling & $\begin{array}{l}\text { Cell Morphology; Cell-To-Cell Signaling and } \\
\text { Interaction; Cellular Function and Maintenance }\end{array}$ \\
\hline $\begin{array}{l}\text { Melanocyte Development } \\
\text { and Pigmentation } \\
\text { Signaling }\end{array}$ & $13 / 79$ & 0.165 & 3.606 & $2.26 \mathrm{E}-2$ & $\begin{array}{l}\text { Cellular Growth, Proliferation and Development; } \\
\text { Growth Factor Signaling }\end{array}$ & $\begin{array}{l}\text { Cellular Development; Tissue Development; Hair and } \\
\text { Skin Development and Function }\end{array}$ \\
\hline $\begin{array}{l}\text { Colorectal Cancer } \\
\text { Metastasis Signaling }\end{array}$ & $28 / 211$ & 0.133 & 5 & $2.27 \mathrm{E}-2$ & Cancer; Disease-Specific Pathways & $\begin{array}{l}\text { Cell Death and Survival; Cell Cycle; Cellular } \\
\text { Development }\end{array}$ \\
\hline Relaxin Signaling & $17 / 115$ & 0.148 & 3 & $2.70 \mathrm{E}-2$ & $\begin{array}{l}\text { Growth Factor Signaling; Organismal Growth and } \\
\text { Development }\end{array}$ & $\begin{array}{l}\text { Cellular Development; Cellular Growth and } \\
\text { Proliferation; Organ Development }\end{array}$ \\
\hline $\begin{array}{l}\text { Neurotrophin/TRK } \\
\text { Signaling }\end{array}$ & $11 / 65$ & 0.169 & 2.714 & $2.85 \mathrm{E}-2$ & $\begin{array}{l}\text { Growth Factor Signaling; Neurotransmitters and } \\
\text { Other Nervous System Signaling }\end{array}$ & $\begin{array}{l}\text { Cellular Growth and Proliferation; Cell Cycle; Cell } \\
\text { Morphology }\end{array}$ \\
\hline SAPK/JNK Signaling & $14 / 90$ & 0.156 & $2-496$ & $2.87 \mathrm{E}-2$ & Apoptosis & $\begin{array}{l}\text { Cell Signaling; Post-Translational Modification; Cell } \\
\text { Death and Survival }\end{array}$ \\
\hline $\begin{array}{l}\text { Role of CHK Proteins in } \\
\text { Cell Cycle Checkpoint } \\
\text { Control }\end{array}$ & $9 / 50$ & 0.18 & 1.134 & $3.17 \mathrm{E}-2$ & Cell Cycle Regulation; Cellular Stress and Injury & $\begin{array}{l}\text { Cell Cycle; DNA Replication, Recombination, and } \\
\text { Repair; Cell Death and Survival }\end{array}$ \\
\hline $\begin{array}{l}\text { Regulation of eIF4 and } \\
\text { p70S6K Signaling }\end{array}$ & $19 / 135$ & 0.141 & 1.155 & $3.20 \mathrm{E}-2$ & $\begin{array}{l}\text { Cell Cycle; DNA Replication, Recombination, and } \\
\text { Repair; Cell Death and Survival }\end{array}$ & Protein Synthesis; Cell Cycle; Cancer \\
\hline
\end{tabular}




\begin{tabular}{|c|c|c|c|c|c|c|}
\hline Pathway & Regulated/total & Ratio & Z-score & $P$ value & Signaling Pathway Category & Top Function \& Diseases \\
\hline IL-1 Signaling & $18 / 83$ & 0.157 & 3.162 & $3.26-2$ & Cytokine Signaling & $\begin{array}{l}\text { Cell-mediated Immune Response; Cellular } \\
\text { Development; Cellular Function and Maintenance }\end{array}$ \\
\hline $\begin{array}{l}\text { Role of NFAT in } \\
\text { Regulation of the Immune } \\
\text { Response }\end{array}$ & $21 / 154$ & 0.136 & 3.873 & $3.41 \mathrm{E}-2$ & $\begin{array}{l}\text { Cellular Immune Response; Humoral Immune } \\
\text { Response; Intracellular and Second Messenger } \\
\text { Signaling }\end{array}$ & $\begin{array}{l}\text { Cellular Development; Hematological System } \\
\text { Development and Function; Hematopoiesis }\end{array}$ \\
\hline $\begin{array}{l}\text { Sphingosine-1-phosphate } \\
\text { Signaling }\end{array}$ & $14 / 93$ & 0.151 & 3.606 & $3.68 \mathrm{E}-2$ & Intracellular and Second Messenger Signaling & $\begin{array}{l}\text { Cellular Development; Embryonic Development; } \\
\text { Organismal Development }\end{array}$ \\
\hline $\begin{array}{l}\text { VEGF Family Ligand- } \\
\text { Receptor Interactions }\end{array}$ & $11 / 69$ & 0.159 & 3.162 & $4.20 \mathrm{E}-2$ & $\begin{array}{l}\text { Cellular Growth, Proliferation and Development; } \\
\text { Growth Factor Signaling }\end{array}$ & $\begin{array}{l}\text { Cell Cycle; Organismal Development; Embryonic } \\
\text { Development }\end{array}$ \\
\hline $\begin{array}{l}\text { FLT3 Signaling in } \\
\text { Hematopoietic Progenitor } \\
\text { Cells }\end{array}$ & $11 / 70$ & 0.157 & 3.317 & $4.60 \mathrm{E}-2$ & Cytokine Signaling & $\begin{array}{l}\text { Cell Cycle; Cellular Development; Hematological } \\
\text { System Development and Function }\end{array}$ \\
\hline p38 MAPK Signaling & $15 / 105$ & 0.143 & 2.673 & $4.70 \mathrm{E}-2$ & $\begin{array}{l}\text { Cellular Immune Response; Cellular Stress and Injury; } \\
\text { Cytokine Signaling; Humoral Immune Response; } \\
\text { Intracellular and Second Messenger Signaling }\end{array}$ & $\begin{array}{l}\text { Gene Expression; Cell Death and Survival; Cellular } \\
\text { Development }\end{array}$ \\
\hline Melatonin Signaling & $10 / 62$ & 0.161 & 2.828 & $4.77 \mathrm{E}-2$ & $\begin{array}{l}\text { Neurotransmitters and Other Nervous System } \\
\text { Signaling }\end{array}$ & $\begin{array}{l}\text { Cell Signaling; Molecular Transport; Small Molecule } \\
\text { Biochemistry }\end{array}$ \\
\hline $\begin{array}{l}\text { GDNF Family Ligand- } \\
\text { Receptor Interactions }\end{array}$ & $10 / 62$ & 0.161 & 3 & $4.77 \mathrm{E}-2$ & $\begin{array}{l}\text { Growth Factor Signaling; Neurotransmitters and } \\
\text { Other Nervous System Signaling }\end{array}$ & $\begin{array}{l}\text { Cellular Development; Cellular Growth and } \\
\text { Proliferation; Nervous System Development and } \\
\text { Function }\end{array}$ \\
\hline $\begin{array}{l}\text { Production of Nitric } \\
\text { Oxide and Reactive } \\
\text { Oxygen Speaces in } \\
\text { Macrophages }\end{array}$ & $21 / 160$ & 0.131 & 2.236 & $4.85 \mathrm{E}-2$ & Cellular Immune Response & $\begin{array}{l}\text { Cell Signaling; Small Molecule Biochemistry; Free } \\
\text { Radical Scavenging }\end{array}$ \\
\hline CNTF Signaling & $8 / 46$ & 0.174 & 2.828 & $4.96 \mathrm{E}-2$ & $\begin{array}{l}\text { Cellular Growth, Proliferation and Development; } \\
\text { Cytokine Signaling; Neurotransmitters and Other } \\
\text { Nervous System Signaling }\end{array}$ & $\begin{array}{l}\text { Cellular Development; Cellular Growth and } \\
\text { Proliferation; Hematological System Development and } \\
\text { Function }\end{array}$ \\
\hline Tec Kinase Signaling & $19 / 142$ & 0.134 & 3.742 & $4.98 \mathrm{E}-2$ & Intracellular and Second Messenger Signaling & \begin{tabular}{|l|} 
Cell-To-Cell Signaling and Interaction; Cellular \\
Function and Maintenance; Inflammatory Response
\end{tabular} \\
\hline \multicolumn{7}{|l|}{ Down-regulated pathways } \\
\hline HIPPO Signaling & $18 / 77$ & 0.234 & $-1,069$ & $1.20 \mathrm{E}-4$ & Organismal Growth and Development & $\begin{array}{l}\text { Cancer; Organismal Injury and Abnormalities; Cell } \\
\text { Cycle }\end{array}$ \\
\hline $\begin{array}{l}\text { NRF2-mediated Oxidative } \\
\text { Stress Response }\end{array}$ & $23 / 136$ & 0.141 & $-3,606$ & $1.92 \mathrm{E}-2$ & $\begin{array}{l}\text { Cellular Stress and Injury; Ingenuity Toxicity List } \\
\text { Pathways }\end{array}$ & $\begin{array}{l}\text { Cell Death and Survival; Post-Translational } \\
\text { Modification; Organismal Survival }\end{array}$ \\
\hline PPAR $\alpha /$ RXR $\alpha$ Activation & $21 / 152$ & 0.138 & $-2,357$ & $3.01 \mathrm{E}-2$ & $\begin{array}{l}\text { Ingenuity Toxicity List Pathways; Nuclear Receptor } \\
\text { Signaling }\end{array}$ & $\begin{array}{l}\text { Energy Production; Lipid Metabolism; Small Molecule } \\
\text { Biochemistry }\end{array}$ \\
\hline
\end{tabular}

Table 2. Significant gene sets with differential gene expression in adipose tissue from women with PCOS versus controls. IPA analyses with $Q<0.05$.

Genome-wide DNA methylation analysis in adipose tissue from women with PCOS. Next we used Illumina Infinium HumanMethylation450k array BeadChips to evaluate the global DNA methylation pattern in adipose tissue from women in cohort 1 . After quality control and filtering, methylation data was obtained in 483,317 CpG sites. The average levels of DNA methylation for these sites were grouped based on their location in relation to the nearest gene (Fig. 3A) or in relation to $\mathrm{CpG}$ islands (Fig. 3B). We found no differences in average adipose tissue DNA methylation between women with PCOS and controls.

Of the $483,317 \mathrm{CpG}$ sites, 63,213 (13\%) were differentially methylated in adipose tissue from women with PCOS and controls $(P<0.05)$ (Table S5). This is 2.6 times more than the expected number with a $P<0.05$ (a $P$ value threshold of $5 \%$ may yield a false positive rate of $5 \%$ in the dataset) and significantly more than would be expected by chance (chi-square test $P<0.0001$ ). After FDR correction, $440 \mathrm{CpG}$ sites were differentially methylated $(Q<0.15)$, Table $S 6$. The most significant CpG site was cg13496119, annotated to $L O C 100129345(Q=0.046$, $P<0.000)$. This uncharacterized locus of unknown function belongs to long noncoding RNAs associated with chromatin remodeling and transcriptional regulation. As judged from absolute difference in DNA methylation between cases and controls, methylation decreased at 22,314 sites (Fig. 3C) and increased at 40,899 sites (Fig. 3D). The majority of differentially methylated sites were in the gene body, intergenic regions, CpG islands, and "open sea" regions (Fig. 3E,F).

To assess the biological relevance of differently methylated genes in adipose tissue from women with PCOS and controls, we used Ingenuity Pathway Analysis software to analyze the 48,426 transcripts annotated to the 63,213 differentially methylated CpG sites $(P<0.05)$. All significantly up- and down-regulated gene sets with differential methylation are presented in (Table S7). Significantly up-regulated canonical pathways relevant to PCOS and T2D are the Wnt $/ \beta$-catenin and planar cell polarity signaling pathways, which regulate glucose transporters, mitochondrial biogenesis, and adipogenesi ${ }^{35}$; and oxidative stress and reactive oxygen species in the macrophage signaling pathway ${ }^{36}$, all involved in glucose regulation, energy metabolism, and obesity. A significantly down-regulated pathway of importance is the NRF-2-mediated oxidative stress response pathway, which helps regulate a wide range of genes in response to environmental stress ${ }^{37}$. Importantly, the NRF-2-mediated oxidative stress response pathway was among the significant gene sets for both differential gene expression and methylation. Differentially methylated genes contributing to up-regulated and down-regulated top canonical pathways are presented in Tables S8 and S9, respectively. 
Next we investigated whether genes previously linked to PCOS, T2D, and obesity in published GWAS $\left(P<5 \times 10^{5}\right.$; http://www.ebi.ac.uk/gwas, accessed on August 20, 2015) were differently methylated in adipose tissue from women with PCOS and controls $(Q<0.15)$. This analysis identified four out of 597 T2D candidate genes $\left(A R F 5^{38}, G A L N T L 4^{39}, R 3 H D M L^{40}\right.$, and $\left.P S M D 6^{40}\right)$ and one obesity candidate gene out of $1238\left(P R O X 1^{41}\right)$ (Table 5), but no PCOS candidate gene. DNA methylation $(P<0.05)$ in the replicated genes (Fig. $2 \mathrm{~A}, \mathrm{~B})$ is shown in Fig. 2E.

Finally, based on data by Chen et al. ${ }^{42}$, potentially cross-reactive probes among our differentially methylated CpG sites with $P<0.05$ are presented in Table S10.

Overlap and associations between gene expression and DNA methylation. Since mRNA expression can be regulated by epigenetic modifications, we next investigated whether genes whose mRNA expression in adipose tissue differed in women with PCOS and controls also differed in DNA methylation. For this analysis, we merged the mRNA expression data and the DNA methylation data (cohort 1 ). All genes that were differentially expressed $(P<0.05)$ were linked to corresponding methylated probes. In total, in 30 individual genes with differential mRNA expression $(Q<0.05)$, we found a corresponding change in 33 DNA methylation sites (Table S11). One of these genes, DMAP1, was replicated in cohort 2 and is involved in DNA methylation and regulation of obesity-related inflammation and developing cancer ${ }^{34,42}$; its mRNA expression was also replicated in cohort 2. Of note, a large number of DNA methyltransferases (DNMTs) genes, a family of enzymes catalyzing the transfer of a methyl group to DNA, were differentially methylated in women with PCOS compared with controls (Table S12). Next, to investigate direct correlations between gene expression and DNA methylation, we performed Spearman's with correction for multiple testing. We included mRNA expression of the 5453 annotated transcripts differentially expressed in adipose tissue from women with PCOS $(P<0.05)$, and DNA methylation of CpG probes located within the cis distance $500 \mathrm{~kb}$ upstream and $100 \mathrm{~kb}$ downstream of the genes. We identified 1913 pairs of "gene-CpG probes" that were significantly correlated after correction for multiple testing $(Q<0.05)$ that corresponded to 349 unique genes (Table S13). 1057 of these correlations were positive $(R h o=0.37-0.61)$ and 856 were negative $(R h o=-0.37-0.69)$.

Several probes of $C D 74$, the gene with the highest increase in expression difference, showed a strong positive correlation with DNA methylation $(R h o=0.611-0.687 ; Q<0.05)$ (Table S13). The CD74 molecule is associated with class II major histocompatibility complex (MHC) class II invariant chain that is involved in regulation of adipogenesis and inflammation ${ }^{43}$. The gene with the strongest negative correlation with DNA methylation was the branched chain keto acid dehydrogenase E1 alpha polypeptide provided (BCKDHA) gene (Table S13). This gene is involved in metabolic signaling and insulin resistance ${ }^{44}$. Representative correlation between mRNA expression and DNA methylation of CD74, BCKDHA, GPT, and PPARG are shown in Fig. 4A-D.

Associations between hyperandrogenemia, glucose homeostasis, or adipocyte size and gene expression or DNA methylation in adipose tissue. Hyperandrogenemia and insulin resistance are the strongest clinical features of PCOS, and adipocytes size is a strong marker for insulin resistance in women with PCOS 9 . Therefore, we tested whether the GDR measured by euglycemic hyperinsulinemic clamp, circulating testosterone measured by LC-MS/MS, or adipocyte size was associated with (1) genes with largest fold changes CD74, CYP1B1 and GPT; (2) candidate genes identified in GWAS studies of PCOS (RAB5B), T2D (PPARG, SVEP1 and BCKDHA), and obesity (RTN4); and, (3) a gene overlapping with methylation (DMAP1). With Spearman's we found a significantly positive correlation between GDR and the expression of $R A B 5 B$ $\left(\mathrm{r}_{\mathrm{s}}=0.211\right), P P A R G\left(\mathrm{r}_{\mathrm{s}}=0.426\right)$, and BCKDHA $\left(\mathrm{r}_{\mathrm{s}}=0.561\right)$, and negative correlation with CD74 $\left(\mathrm{r}_{\mathrm{s}}=-0.281\right)$, SVEP1 $\left(\mathrm{r}_{\mathrm{s}}=-0.421\right)$, and CYP1B1 $\left(\mathrm{r}_{\mathrm{s}}=-0.325\right)$. Circulating testosterone correlated positively with the expression of CD74 $\left(\mathrm{r}_{\mathrm{s}}=0.356\right), C Y P 1 B 1\left(\mathrm{r}_{\mathrm{s}}=0.219\right)$ and RTN4 $\left(\mathrm{r}_{\mathrm{s}}=0.261\right)$, and negatively with the expression of GPT $\left(\mathrm{r}_{\mathrm{s}}=-0.317\right), \operatorname{PPARG}\left(\mathrm{r}_{\mathrm{s}}=-0.269\right), B C K D H A\left(\mathrm{r}_{\mathrm{s}}=-0.463\right)$, and DMAP1 $\left(\mathrm{r}_{\mathrm{s}}=-0.339\right)$. Adipocyte size was positively correlated with CD74 $\left(\mathrm{r}_{\mathrm{s}}=0.425\right), S V E P 1\left(\mathrm{r}_{\mathrm{s}}=0.525\right), R T N 4\left(\mathrm{r}_{\mathrm{s}}=0.217\right)$, and CYP1B1 $\left(\mathrm{r}_{\mathrm{s}}=0.284\right)$, and negatively associated with PPARG $\left(\mathrm{r}_{\mathrm{s}}=-0.449\right)$ and $B C K D H A\left(\mathrm{r}_{\mathrm{s}}=-0.587\right)$. Correlations that remained significant after adjustments for BMI are presented in Fig. 5A-L.

\section{Discussion}

This study shows that genome-wide mRNA expression in subcutaneous adipose tissue is altered in women with PCOS and that several genes are associated with insulin resistance, adipocyte size, and hyperandrogenemia. Among the top up- and down-regulated canonical pathways relevant to PCOS and T2D, we found gene sets representing the PI3K/AKT, ERK/MAPK, androgen, TGF- $\beta$, telomerase, and NRF2-mediated oxidative stress response signaling pathways. We also demonstrate for the first time that genome-wide DNA methylation alterations in adipose tissue were larger than expected. However, correction for multiple testing reduced the number of differentially methylated sites to 440 . Also, we found more than 1900 pairs of "gene-CpG probes" that were significantly correlated after correction for multiple testing and corresponded to 349 unique genes. Since PCOS is a polygenic disease, the combined effect of several modest changes in DNA methylation might contribute to the pathogenesis of PCOS. This speculation is supported by other studies demonstrating a relative modest difference $(0.13 \%$ to $11 \%)$ in DNA methylation in different target tissues ${ }^{45}$. Also, an absolute change of a few percent could make a relatively large difference, as we found in a recent study in which the fold change in DNA methylation ranged from 0.54 to 1.84 between the groups ${ }^{45}$. Consistent with these observations, differences of DNA methylation in the present study ranged from 0.24 to 6.28 .

We identified several genes with differential mRNA expression and corresponding changes in DNA methylation, indicating that altered DNA methylation may have the potential to influence the expression of corresponding genes. Genes with the largest expression differences e.g. CD74, CYP1B1, and GPT were strongly 

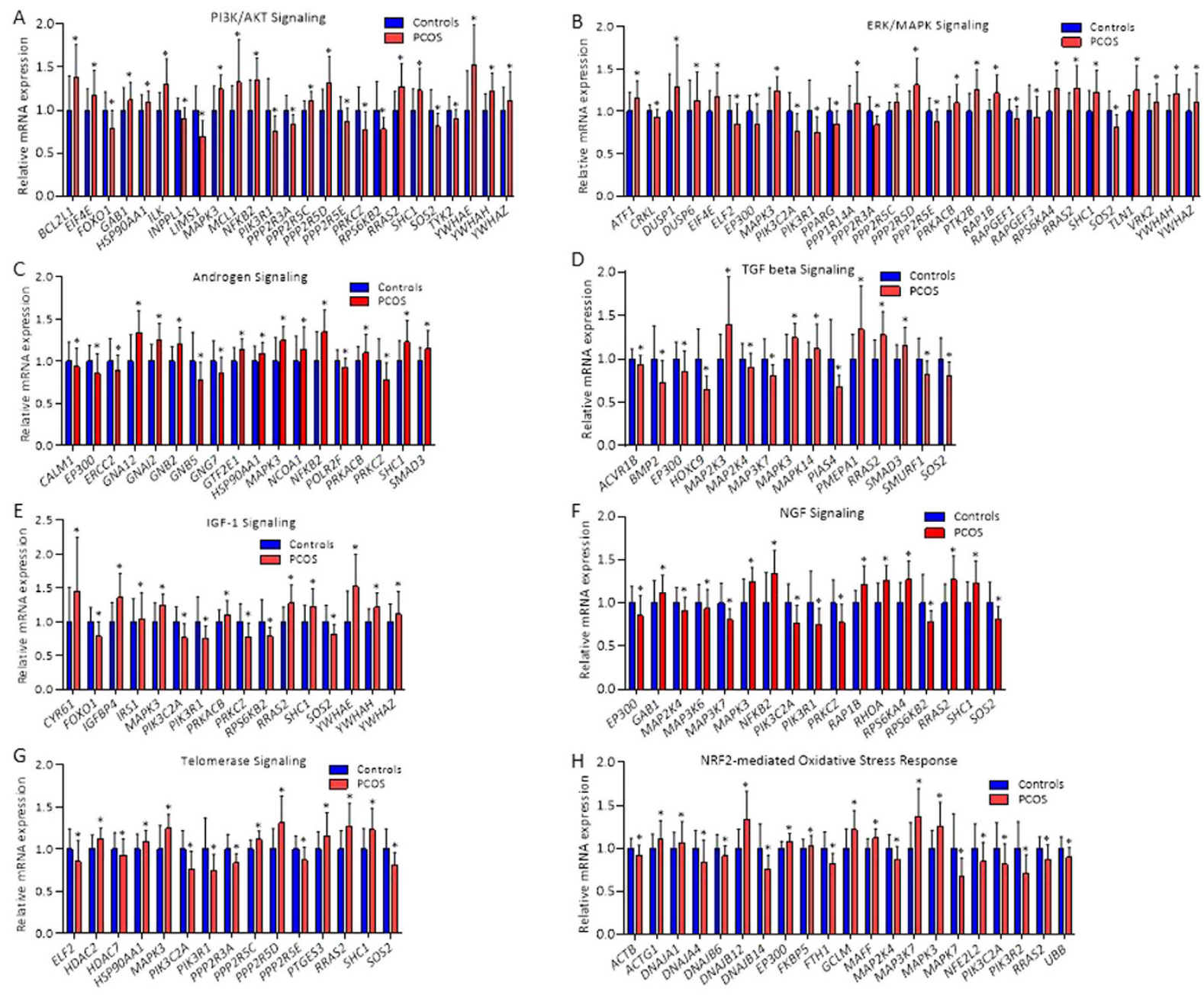

Figure 1. Gene sets contributing to selected significant top canonical pathways, identified by Ingenuity Pathway Analysis, of possible relevance to PCOS and T2D. Up-regulated canonical pathways: (A) PI3K/AKT Signaling pathway, (B) ERK/MAPK signaling pathway, (C) Androgen receptor signaling pathway, (D) TGF- $\beta$ signaling pathway, (E) IGF1-1 signaling pathway, (F) NGF signaling pathway, and (G) Telomerase signaling pathway. Down-regulated canonical pathway: (H) NRF2-mediated oxidative stress response signaling pathway. Values are mean $\pm \mathrm{SD} .{ }^{\star} P<0.05$.

associated with DNA methylation after FDR corrections. These genes are involved in adipogenesis and inflammatory response $(C D 74)^{46}$, in metabolism of sex steroids and adipogenesis $(C Y P 1 B 1)^{47}$, and in glucose and amino acid metabolism $(G P T)^{33}$. In candidate genes for PCOS (RAB5B), T2D (PPARG and SVEP1), and methylation (DMAP1) we found that a decrease in mRNA expression was paralleled with an increase in DNA methylation, consistent with previous functional in vitro studies demonstrating that an increase in DNA methylation reduces transcriptional activity ${ }^{48,49}$. Many of the up-regulated genes had a parallel increase in DNA methylation. One possible explanation is that these $\mathrm{CpG}$ sites are in the gene body region, as evidenced by the over-representation of differentially methylated sites we found in this region. Importantly, DNA methylation in the gene body positively affects gene expression ${ }^{50}$.

Although changes in mRNA expression were more pronounced than changes in DNA methylation, we found a large number of differentially expressed genes and methylated CpG sites that were significantly correlated after FDR correction. Of note, changes in methylation can be targets for other kind of transcriptional regulation, microRNAs, or histone modifications. There may also be an interaction between nongenetic, epigenetic, and genetic factors affecting gene expression and subsequent development of polygenic diseases such as PCOS, T2D, and obesity ${ }^{51-54}$. Support for a genetic effect comes from a study demonstrating that T2D-related single nucleotide polymorphisms (SNPs) are CpG-SNPs, which affect DNA methylation and gene expression in human pancreatic cells ${ }^{55}$, and from studies of multiple tissues from twins ${ }^{56,57}$. Of note, studies in twins indicate that genetic influences explain more than $70 \%$ of PCOS pathogenesis ${ }^{58}$. Nevertheless, recent GWAS have not identified SNPs that could explain this estimated heritability ${ }^{26,59}$, which therefore might reflect contributions of epigenetic variations.

The first GWAS on Han Chinese populations identified more than 10 susceptibility loci for PCOS, including $R A B 5 B^{26,59}$. This gene encodes the Ras-related protein RAB5B. Although the functional role of this PCOS 


\begin{tabular}{|c|c|c|c|c|c|c|}
\hline \multicolumn{7}{|l|}{ Up-regulated genes } \\
\hline Symbol & Gene Description & $\begin{array}{l}\text { Controls } \\
\text { mean } \pm \text { SD }\end{array}$ & $\begin{array}{c}\mathrm{PCOS} \\
\text { mean } \pm S D\end{array}$ & Difference (\%) & $p$ value & $Q$ value \\
\hline$C D 74$ & $\begin{array}{l}\text { CD74 molecule, major histocompatibility complex, } \\
\text { class II invariant chain }\end{array}$ & $59.4 \pm 1.4$ & $93.7 \pm 1.5$ & 57.8 & $8 \mathrm{E}-06$ & $1 \mathrm{E}-03$ \\
\hline SNORD48 & small nucleolar RNA, C/D box 48 & $11.2 \pm 1.4$ & $17.5 \pm 1.5$ & 56.4 & $3 \mathrm{E}-07$ & $1 \mathrm{E}-04$ \\
\hline APOLD1 & apolipoprotein L domain-containing 1 & $217.2 \pm 1.6$ & $330.9 \pm 1.6$ & 52.3 & 9E-06 & $1 \mathrm{E}-03$ \\
\hline IDO1 & indoleamine 2,3-dioxygenase 1 & $18 \pm 1.5$ & $26.9 \pm 1.6$ & 49.6 & 9E-04 & $2 \mathrm{E}-02$ \\
\hline MYL9 & myosin, light chain 9, regulatory & $267.2 \pm 1.3$ & $397.2 \pm 1.3$ & 48.6 & $2 \mathrm{E}-07$ & $7 \mathrm{E}-05$ \\
\hline NRCAM & neuronal cell-adhesion molecule & $102.3 \pm 1.5$ & $151.2 \pm 1.5$ & 47.8 & $4 \mathrm{E}-04$ & $1 \mathrm{E}-02$ \\
\hline CYP1B1 & $\begin{array}{l}\text { cytochrome P450, family } 1 \text {, subfamily B, } \\
\text { polypeptide } 1\end{array}$ & $61.3 \pm 1.4$ & $89.8 \pm 1.4$ & 46.3 & $1 \mathrm{E}-05$ & $1 \mathrm{E}-03$ \\
\hline CYR61 & cysteine-rich, angiogenic inducer, 61 & $169.7 \pm 1.5$ & $248 \pm 1.7$ & 46.1 & $3 \mathrm{E}-04$ & $1 \mathrm{E}-02$ \\
\hline AZIN1 & antizyme inhibitor 1 & $33.5 \pm 1.6$ & $48.9 \pm 1.7$ & 45.7 & $8 \mathrm{E}-04$ & $2 \mathrm{E}-02$ \\
\hline STC1 & stanniocalcin 1 & $28 \pm 1.5$ & $40.4 \pm 1.6$ & 44.3 & $3 \mathrm{E}-03$ & $4 \mathrm{E}-02$ \\
\hline NEK7 & NIMA-related kinase 7 & $40.8 \pm 1.4$ & $58 \pm 1.4$ & 42.2 & $1 \mathrm{E}-05$ & $1 \mathrm{E}-03$ \\
\hline$U C P 2$ & $\begin{array}{l}\text { uncoupling protein } 2 \text { (mitochondrial, proton } \\
\text { carrier) }\end{array}$ & $352.9 \pm 1.3$ & $499.3 \pm 1.4$ & 41.5 & $6 \mathrm{E}-06$ & $8 \mathrm{E}-04$ \\
\hline C1S & complement component $1, \mathrm{~s}$ subcomponent & $33.7 \pm 1.4$ & $47.5 \pm 1.4$ & 41.0 & $1 \mathrm{E}-04$ & $6 \mathrm{E}-03$ \\
\hline PLEKHO2 & $\begin{array}{l}\text { pleckstrin homology domain containing, family } \mathrm{O} \\
\text { member } 2\end{array}$ & $138 \pm 1.4$ & $193.4 \pm 1.3$ & 40.1 & $8 \mathrm{E}-05$ & $4 \mathrm{E}-03$ \\
\hline SNX10 & sorting nexin 10 & $148.6 \pm 1.6$ & $206.7 \pm 1.5$ & 39.1 & $5 \mathrm{E}-04$ & $1 \mathrm{E}-02$ \\
\hline C1R & complement component 1 , $r$ subcomponent & $97.4 \pm 1.4$ & $134.2 \pm 1.4$ & 37.8 & $2 \mathrm{E}-03$ & $3 \mathrm{E}-02$ \\
\hline SEMA3C & $\begin{array}{l}\text { sema domain, immunoglobulin domain (Ig), short } \\
\text { basic domain, secreted, (semaphorin) 3C }\end{array}$ & $176.5 \pm 1.4$ & $242.5 \pm 1.4$ & 37.4 & $1 \mathrm{E}-04$ & $6 \mathrm{E}-03$ \\
\hline LOC100132793 & chromosome 8 open reading frame 88 & $12.1 \pm 1.3$ & $16.5 \pm 1.3$ & 36.2 & $8 \mathrm{E}-08$ & $4 \mathrm{E}-05$ \\
\hline SIK1 & salt-inducible kinase 1 & $25.7 \pm 1.4$ & $35 \pm 1.4$ & 36.1 & $3 \mathrm{E}-05$ & $2 \mathrm{E}-03$ \\
\hline LOC100133511 & uncharacterized LOC100131581 & $77 \pm 1.4$ & $104.6 \pm 1.4$ & 35.9 & $2 \mathrm{E}-04$ & $7 \mathrm{E}-03$ \\
\hline MYL9 & myosin, light chain 9, regulatory & $405.4 \pm 1.3$ & $549.5 \pm 1.3$ & 35.6 & $1 \mathrm{E}-05$ & $1 \mathrm{E}-03$ \\
\hline EFEMP1 & $\begin{array}{l}\text { EGF containing fibulin-like extracellular matrix } \\
\text { protein } 1\end{array}$ & $321 \pm 1.4$ & $434.9 \pm 1.4$ & 35.5 & $2 \mathrm{E}-03$ & $3 \mathrm{E}-02$ \\
\hline GSTT2B & glutathione S-transferase theta 2 & $21.3 \pm 1.5$ & $28.8 \pm 1.4$ & 35.3 & $8 \mathrm{E}-04$ & $2 \mathrm{E}-02$ \\
\hline CXCR4 & chemokine (C-X-C motif) receptor 4 & $24.4 \pm 1.6$ & $32.9 \pm 1.5$ & 34.9 & $2 \mathrm{E}-03$ & $4 \mathrm{E}-02$ \\
\hline GSTT2 & glutathione S-transferase theta 2 & $16.8 \pm 1.5$ & $22.7 \pm 1.4$ & 34.8 & $1 \mathrm{E}-03$ & $2 \mathrm{E}-02$ \\
\hline \multicolumn{7}{|l|}{ Upregulated genes } \\
\hline LOC100132761 & Uncharacterized & $104.1 \pm 2.1$ & $44.3 \pm 2.7$ & -57.4 & $3 \mathrm{E}-05$ & $2 \mathrm{E}-03$ \\
\hline SLC7A10 & $\begin{array}{l}\text { Solute carrier family } 7 \text { (neutral amino acid } \\
\text { transporter light chain, asc system), member } 10\end{array}$ & $655.1 \pm 1.5$ & $391.6 \pm 1.9$ & -40.2 & $3 \mathrm{E}-03$ & $4 \mathrm{E}-02$ \\
\hline PKD1L2 & polycystic kidney disease 1-like 2 & $203.3 \pm 1.5$ & $123.9 \pm 1.7$ & -39.1 & $2 \mathrm{E}-03$ & $3 \mathrm{E}-02$ \\
\hline LOC389342 & maltase-glucoamylase (alpha-glucosidase) & $2047.4 \pm 1.3$ & $1253.2 \pm 1.6$ & -38.8 & $2 \mathrm{E}-05$ & $2 \mathrm{E}-03$ \\
\hline MYOC & $\begin{array}{l}\text { myocilin, trabecular meshwork inducible } \\
\text { glucocorticoid response }\end{array}$ & $126 \pm 1.5$ & $79.6 \pm 1.6$ & -36.9 & $1 \mathrm{E}-03$ & $2 \mathrm{E}-02$ \\
\hline C21orf81 & $\begin{array}{l}\text { ankyrin repeat domain } 20 \text { family, member A11, } \\
\text { pseudogene }\end{array}$ & $98.1 \pm 1.5$ & $63.2 \pm 1.6$ & -35.6 & $6 \mathrm{E}-04$ & $1 \mathrm{E}-02$ \\
\hline LOC729222 & liprin-beta-1-like & $49 \pm 1.3$ & $31.5 \pm 1.3$ & -35.6 & $3 \mathrm{E}-11$ & $5 \mathrm{E}-07$ \\
\hline COL8A1 & collagen, type VIII, alpha 1 & $456 \pm 1.6$ & $297.7 \pm 1.5$ & -34.7 & $2 \mathrm{E}-04$ & $7 \mathrm{E}-03$ \\
\hline SYT17 & synaptotagmin XVII & $33 \pm 1.5$ & $21.6 \pm 1.6$ & -34.4 & $4 \mathrm{E}-03$ & $5 \mathrm{E}-02$ \\
\hline ANKRD20A1 & ankyrin repeat domain 20 family, member A4 & $417.4 \pm 1.4$ & $276.5 \pm 1.4$ & -33.8 & $4 \mathrm{E}-06$ & $6 \mathrm{E}-04$ \\
\hline LOC100128888 & uncharacterized & $34.2 \pm 1.3$ & $22.8 \pm 1.3$ & -33.4 & $1 \mathrm{E}-10$ & $5 \mathrm{E}-07$ \\
\hline LOC654342 & lymphocyte-specific protein 1 pseudogene & $55.1 \pm 1.3$ & $36.7 \pm 1.4$ & -33.4 & $4 \mathrm{E}-07$ & $1 \mathrm{E}-04$ \\
\hline PPFIBP1 & $\begin{array}{l}\text { PTPRF interacting protein, binding protein } 1 \\
\text { (liprin beta 1) }\end{array}$ & $43.4 \pm 1.3$ & $29.1 \pm 1.3$ & -32.9 & 7E-07 & $2 \mathrm{E}-04$ \\
\hline TSPAN18 & tetraspanin 18 & $162.5 \pm 1.3$ & $109.2 \pm 1.3$ & -32.8 & 1E-08 & $1 \mathrm{E}-05$ \\
\hline NBPF20 & neuroblastoma breakpoint family, member 15 & $1226.5 \pm 1.3$ & $826.3 \pm 1.5$ & -32.6 & $8 \mathrm{E}-05$ & $4 \mathrm{E}-03$ \\
\hline FAM13A & family with sequence similarity 13 , member $\mathrm{A}$ & $568.1 \pm 1.4$ & $395.2 \pm 1.5$ & -30.4 & $3 \mathrm{E}-04$ & $1 \mathrm{E}-02$ \\
\hline NFIC & $\begin{array}{l}\text { nuclear factor I/C (CCAAT-binding transcription } \\
\text { factor) }\end{array}$ & $308.9 \pm 1.2$ & $215.9 \pm 1.3$ & -30.1 & $9 \mathrm{E}-11$ & $5 \mathrm{E}-07$ \\
\hline FAM126B & family with sequence similarity 126 , member B & $146.6 \pm 1.3$ & $103.2 \pm 1.4$ & -29.6 & 7E-05 & $4 \mathrm{E}-03$ \\
\hline UGP2 & UDP-glucose pyrophosphorylase 2 & $32.6 \pm 1.5$ & $23 \pm 1.5$ & -29.5 & $2 \mathrm{E}-04$ & $7 \mathrm{E}-03$ \\
\hline MOGAT1 & monoacylglycerol O-acyltransferase 1 & $33.7 \pm 1.4$ & $23.9 \pm 1.4$ & -29.2 & $3 \mathrm{E}-04$ & $1 \mathrm{E}-02$ \\
\hline LOC100129905 & uncharacterized LOC100128905 & $38.2 \pm 1.3$ & $27 \pm 1.4$ & -29.2 & $2 \mathrm{E}-05$ & $2 \mathrm{E}-03$ \\
\hline FAM129A & family with sequence similarity 129 , member A & $162.1 \pm 1.4$ & $115.1 \pm 1.5$ & -29.0 & $5 \mathrm{E}-06$ & $8 \mathrm{E}-04$ \\
\hline ntinue & & & & & & \\
\hline
\end{tabular}




\begin{tabular}{|l|l|c|c|c|c|c|}
\hline \multicolumn{2}{|l|}{ Up-regulated genes } & \multicolumn{1}{|c|}{$\begin{array}{l}\text { PCOS } \\
\text { Symbol }\end{array}$} & $\begin{array}{c}\text { Controls } \\
\text { mean } \pm \text { SD }\end{array}$ & $\begin{array}{c}\text { mean } \pm \text { SD } \\
\text { Difference (\%) }\end{array}$ & $\boldsymbol{p}$ value & $\boldsymbol{Q}$ value \\
\hline LOC100128899 & uncharacterized LOC100128979 & $172.3 \pm 1.4$ & $122.4 \pm 1.4$ & -29.0 & $1 \mathrm{E}-03$ & $2 \mathrm{E}-02$ \\
\hline$G P T$ & $\begin{array}{l}\text { glutamic-pyruvate transaminase (alanine } \\
\text { aminotransferase) }\end{array}$ & $161.1 \pm 1.3$ & $114.6 \pm 1.5$ & -28.9 & $2 \mathrm{E}-03$ & $4 \mathrm{E}-02$ \\
\hline C1orf152 & profilin 1 pseudogene 2 & $30.1 \pm 1.3$ & $21.4 \pm 1.3$ & -28.7 & $6 \mathrm{E}-06$ & $8 \mathrm{E}-04$ \\
\hline
\end{tabular}

Table 3. Fifty individual genes with the largest mRNA expression differences in adipose tissue between PCOS $(n=64)$ and controls $(n=30)(Q<0.05)$ including uncharacterized (LOC) genes.

\begin{tabular}{|c|c|c|c|c|c|c|}
\hline Symbol & Illumina ID & $\begin{array}{c}\text { Controls } \\
\text { mean } \pm \text { SD }\end{array}$ & $\begin{array}{c}\text { PCOS } \\
\text { mean } \pm S D\end{array}$ & Difference (\%) & $p$ values & $Q$ values \\
\hline \multicolumn{7}{|l|}{ PCOS } \\
\hline $\begin{array}{l}\text { RAB5B (Rabaptin } 5 \beta \text { or member } \\
\text { RAS oncogene family) }\end{array}$ & 2850626 & $1260.2 \pm 1$ & $1195.5 \pm 1.1$ & -5.14 & 0.000 & 0.009 \\
\hline \multicolumn{7}{|l|}{ Diabetes } \\
\hline $\begin{array}{l}\text { C2orf79 (peptidyl-tRNA hydrolase } \\
\text { domain containing 1) }\end{array}$ & 3170725 & $64.3 \pm 1.1$ & $61.2 \pm 1.1$ & -4.80 & 0.002 & 0.034 \\
\hline $\begin{array}{l}\text { CCDC102A (coiled-coil domain } \\
\text { containing 102A) }\end{array}$ & 1660681 & $76.3 \pm 1.2$ & $70 \pm 1.2$ & -8.21 & 0.000 & 0.009 \\
\hline $\begin{array}{l}\text { CLEC16A (C-type lectin domain } \\
\text { family } 16, \text { member } A)\end{array}$ & 160224 & $134.4 \pm 1.1$ & $122.1 \pm 1.1$ & -9.19 & 0.000 & 0.001 \\
\hline $\begin{array}{l}\text { IKZF4 (IKAROS family zinc finger } \\
4 \text { (Eos)) }\end{array}$ & 5550608 & $29.6 \pm 1.2$ & $24.8 \pm 1.2$ & -16.23 & 0.001 & 0.024 \\
\hline IRS1 (Insulin receptor substrate) & 1710091 & $240.4 \pm 1.3$ & $257.3 \pm 1.4$ & 7.03 & 0.001 & 0.024 \\
\hline $\begin{array}{l}\text { MEG3 (maternally expressed } 3 \\
\text { (non-protein coding)) }\end{array}$ & 3360113 & $310.6 \pm 1.3$ & $235.4 \pm 1.4$ & -24.22 & 0.001 & 0.021 \\
\hline $\begin{array}{l}\text { PHTF1 (putative homeodomain } \\
\text { transcription factor 1) }\end{array}$ & 6900521 & $70.6 \pm 1.1$ & $79.6 \pm 1.1$ & 12.77 & 0.000 & 0.011 \\
\hline POMC (proopiomelanocortin) & 5080072 & $34.6 \pm 1.3$ & $28.9 \pm 1.3$ & -16.42 & 0.003 & 0.044 \\
\hline $\begin{array}{l}\text { PPARG (peroxisome proliferator- } \\
\text { activated receptor gamma) }\end{array}$ & 830019 & $2866 \pm 1.1$ & $2478 \pm 1.2$ & -13.54 & 0.001 & 0.025 \\
\hline $\begin{array}{l}\text { RBMS1 (RNA binding motif, single } \\
\text { stranded interacting protein 1) }\end{array}$ & 4150639 & $526.1 \pm 1.1$ & $586.7 \pm 1.1$ & 11.52 & 0.000 & 0.009 \\
\hline $\begin{array}{l}\text { SGCG (8sarcoglycan. gamma } \\
\text { (35kDa dystrophin-associated } \\
\text { glycoprotein) }\end{array}$ & 5670082 & $138.5 \pm 1.2$ & $115.6 \pm 1.2$ & -16.50 & 0.000 & 0.009 \\
\hline $\begin{array}{l}\text { SPRY2 (sprouty homolog } 2 \\
\text { (Drosophila)) }\end{array}$ & 6590575 & $284.4 \pm 1.2$ & $304.7 \pm 1.2$ & 7.12 & 0.000 & 0.010 \\
\hline $\begin{array}{l}\text { SVEP1 (sushi. von Willebrand } \\
\text { factor type A, EGF and pentraxin } \\
\text { domain containing 1) }\end{array}$ & 6180554 & $932.8 \pm 1.2$ & $837 \pm 1.4$ & -10.27 & 0.000 & 0.001 \\
\hline $\begin{array}{l}\text { TNRC6A (trinucleotide repeat } \\
\text { containing } 6 A \text { ) }\end{array}$ & 130386 & $19.5 \pm 1.2$ & $17.2 \pm 1.2$ & -12.15 & 0.000 & 0.014 \\
\hline $\begin{array}{l}\text { TRAFD1 (TRAF-type zinc finger } \\
\text { domain containing 1) }\end{array}$ & 1570129 & $90.4 \pm 1.1$ & $82.3 \pm 1.1$ & -8.93 & 0.001 & 0.019 \\
\hline TYK2 (tyrosine kinase 2) & 6900424 & $404.9 \pm 1.1$ & $380 \pm 1.1$ & -6.17 & 0.003 & 0.045 \\
\hline $\begin{array}{l}\text { WWOX (WW domain containing } \\
\text { oxidoreductase) }\end{array}$ & 6450189 & $34.5 \pm 1.2$ & $29 \pm 1.2$ & -15.92 & 0.000 & 0.001 \\
\hline \multicolumn{7}{|l|}{ Obesity } \\
\hline $\begin{array}{l}\text { ASAH1 (N-acylsphingosine } \\
\text { amidohydrolase [acid ceramidase] } \\
\text { 1) }\end{array}$ & 5420332 & $17.7 \pm 1.2$ & $19.9 \pm 1.2$ & 12.38 & 0.000 & 0.012 \\
\hline LEPR (leptin receptor) & 6480348 & $25.7 \pm 1.2$ & $30.2 \pm 1.2$ & 17.63 & 0.002 & 0.030 \\
\hline RTN4 (reticulon 4) & 780402 & $1202.6 \pm 1.3$ & $1468 \pm 1.2$ & 22.07 & 0.000 & 0.001 \\
\hline RTN4 (reticulon 4) & 2230161 & $5505.2 \pm 1.1$ & $5988.2 \pm 1.1$ & 8.77 & 0.003 & 0.040 \\
\hline $\begin{array}{l}\text { TSEN34 (TSEN34 tRNA splicing } \\
\text { endonuclease subunit) }\end{array}$ & 5890497 & $268.1 \pm 1.1$ & $282.9 \pm 1.1$ & 5.53 & 0.004 & 0.049 \\
\hline
\end{tabular}

Table 4. Genes previously linked to PCOS, type 2 diabetes (T2D) and obesity in published GWAS with differential expression in adipose tissue from women with PCOS $(n=64)$ compared with controls $(n=30)$ (cohort 1).

susceptible gene in adipose tissue is unknown, $R A B 5 B$ expression was down-regulated both in the discovery cohort and in the replication cohort and was accompanied by an up-regulation in DNA methylation. Genes 
A

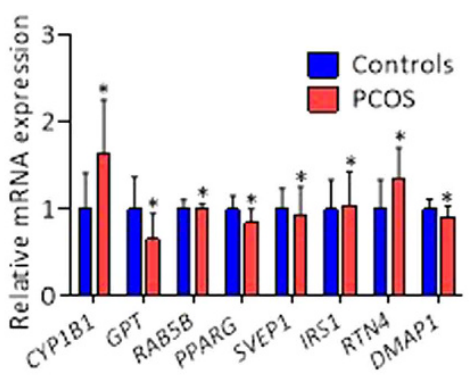

C
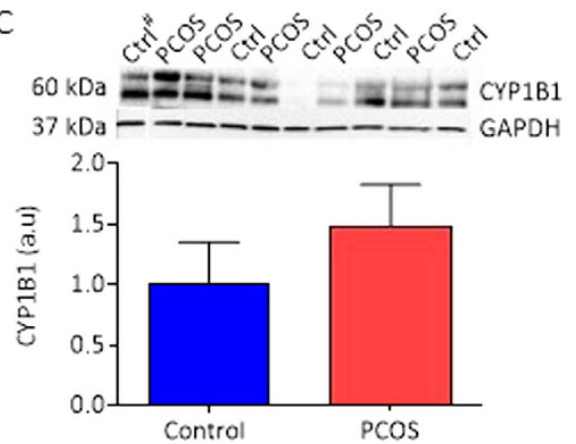

$\mathrm{B}$

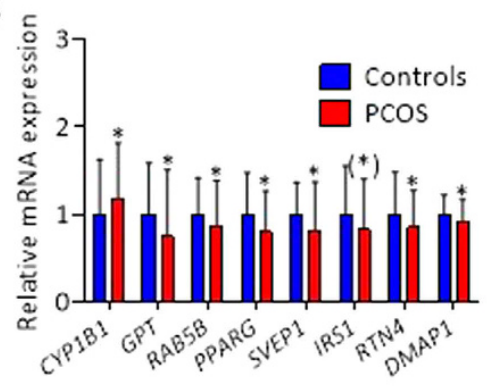

D
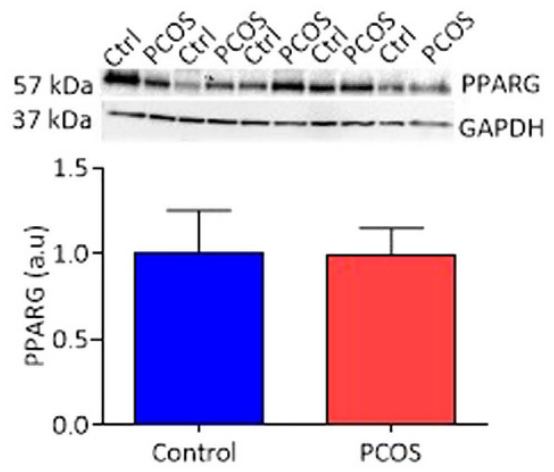

ES

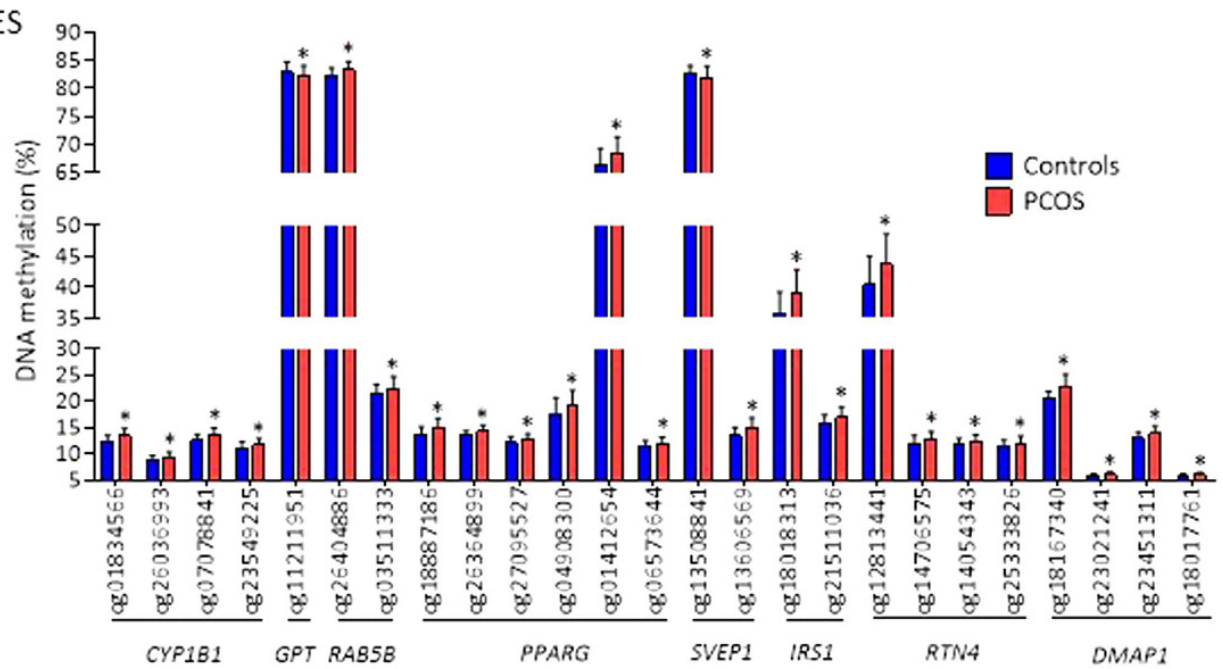

Figure 2. Selected genes relevant to PCOS that were differentially expressed in cohort 1 and replicated in cohort 2. (A) Expression data of selected genes from the Illumina HumanHT- 12 v4 Expression BeadChip array (cohort 1). (B) Replication of gene expression data from the array by qPCR in adipose tissue from 21 unrelated women with PCOS and 21 controls (cohort 2). Protein expression of CYP1B1 (C) and PPARG (D) in control $(n=5)$ and PCOS $(n=5)$ are presented. (E) Differential DNA methylation of biologically validated genes. Values for gene expression are mean $\pm \mathrm{SD}$ and for proteins mean \pm SEM. ${ }^{\star} P<0.05\left(^{*}\right) P=0.056$. \# Sample run on a different membrane.

acting through Rab5b-dependent post-translational regulation of $\beta 1 / \beta 2$ integrins ${ }^{60}$, indicates a functional role of $R A B 5 B$ in a target tissue.

A very recent GWAS of women of European ancestry who had a classic PCOS phenotype (hyperandrogenism and irregular menstruation) identified two novel genetic susceptibility loci that mapped to chr $8 \mathrm{p} 32.1$ and chr 11p14. $1^{61}$. Interestingly, we found differential DNA methylation in all four genes that mapped to the chr 8p32.1 PCOS candidate locus (NEIL2, FDFT1, GATA4, and CTSB) and differential expression of FDF1 and CTSB. Further, we found differential gene expression and DNA methylation of one of the most promising functional candidate genes-ARL14EP, which maps to chr 11p14.1-but no changes in the FSHB expression or methylation in adipose tissue from women with PCOS. In the GWAS study mentioned above, there was no evidence of transcriptional activation and microarray analysis revealed low levels in adipocytes.

We also found that two T2D susceptibility genes, $P P A R G^{27}$ and $S V E P 1^{28}$, followed the same pattern of decreased expression and increased DNA methylation, and both showed a strong negative correlation between "gene-CpG probes" after multiple corrections. PPARG, a master regulator of adipocyte differentiation, directly 
A
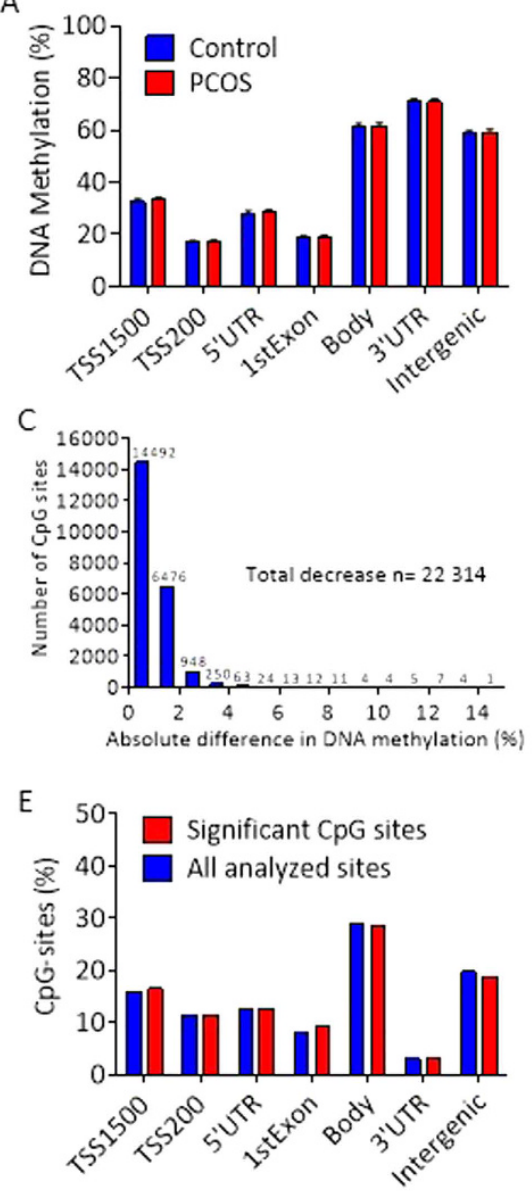

B

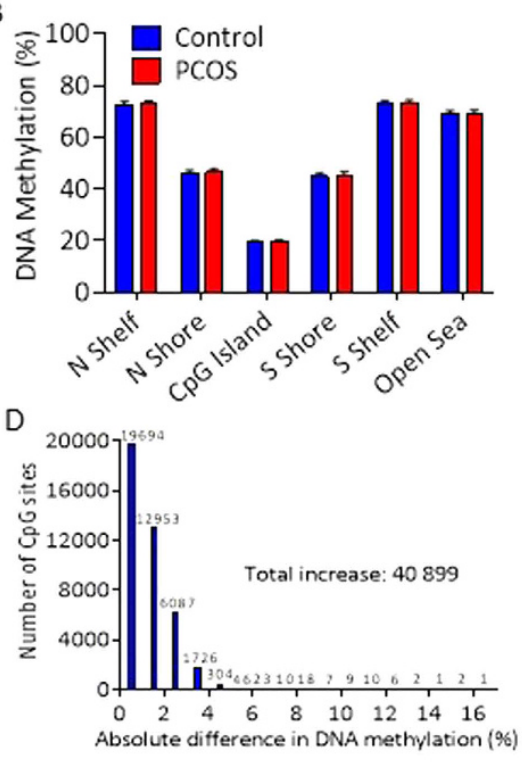

$\mathrm{F}$

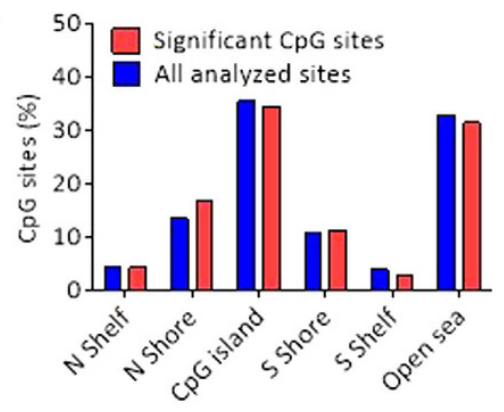

Figure 3. Effect of PCOS on global DNA methylation in human adipose tissue. Global DNA methylation was calculated as the average DNA methylation of all CpG sites in each annotated region on the Infinium Human Methylation 450 BeadChip presented for (A) the nearest gene region and (B) nearest CpG island region (mean \pm SD). Absolute difference in DNA methylation of 63,213 individual sites divided into (C) sites with less methylation and (D) sites with more methylation in 64 women with PCOS than in 30 controls (cohort 1). Distribution of significant sites compared with all analyzed sites in relation to nearest gene region (E) and nearest CpG island region (F). TSS, proximal promotor defined as 200 or 1500 bp upstream of the transcription site; Shore, flanking region of CpG island (0-2000 bp); Shelf, regions flanking island shores (2000-4000 bp from the $\mathrm{CpG}$ island).

\begin{tabular}{|c|c|c|c|c|c|c|}
\hline Symbol (name) & Illumina ID & $\begin{array}{l}\text { Controls } \\
\text { mean } \pm \text { SD }\end{array}$ & $\begin{array}{c}\text { PCOS } \\
\text { mean } \pm S D\end{array}$ & Difference (\%) & $P$ values & $Q$ values \\
\hline \multicolumn{7}{|l|}{ Diabetes } \\
\hline ARF5 (ADP-ribosylation factor 5) & $\operatorname{cg} 15802323$ & $17.4 \pm 1.4$ & $19.1 \pm 1.9$ & 1.69 & $7.8 \mathrm{E}-05$ & 0.15 \\
\hline $\begin{array}{l}\text { GALNTL4 (polypeptide } \\
\text { N-acetylgalactosaminyltransferase 18) }\end{array}$ & $\operatorname{cg} 04807025$ & $88.6 \pm 0.7$ & $87.9 \pm 1.1$ & -0.78 & $7.1 \mathrm{E}-06$ & 0.11 \\
\hline R3HDML (R3H domain containing-like) & $\operatorname{cg} 17692403$ & $15.3 \pm 1.7$ & $17.6 \pm 2.4$ & 2.26 & $9.2 \mathrm{E}-05$ & 0.15 \\
\hline $\begin{array}{l}\text { PSMD6 (26S proteasome non-ATPase } \\
\text { regulatory subunit 6) }\end{array}$ & $\operatorname{cg} 07662771$ & $77.5 \pm 2$ & $74.7 \pm 3.4$ & -2.78 & $1.2 \mathrm{E}-04$ & 0.15 \\
\hline \multicolumn{7}{|l|}{ Obesity } \\
\hline PROX1 (prospero homeobox 1) & $\operatorname{cg} 22489498$ & $9.2 \pm 0.8$ & $10 \pm 0.8$ & 0.79 & $1.5 \mathrm{E}-05$ & 0.11 \\
\hline
\end{tabular}

Table 5. Genes previously linked to type 2 diabetes and obesity in published GWAS with differential methylation $(Q<0.15)$ in adipose tissue from women with $\operatorname{PCOS}(n=64)$ versus controls $(n=30)(\operatorname{cohort} 1)$.

controls the expression of genes involved in lipid transport and metabolism, adipokine production, and insulin signaling ${ }^{62}$; it is a target for insulin-sensitizing drugs such as glitazones, which improve plasma glucose maintenance in patients with T2D ${ }^{63}$. Previously we found higher levels of DNA methylation of PPARG in adipose tissue in subjects with T2D than in controls ${ }^{21}$. PPARG also protects against vascular calcification by inducing 
A

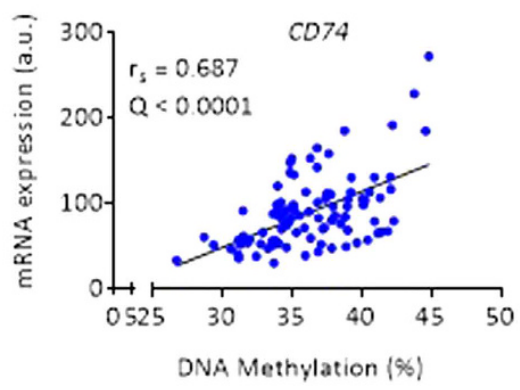

C

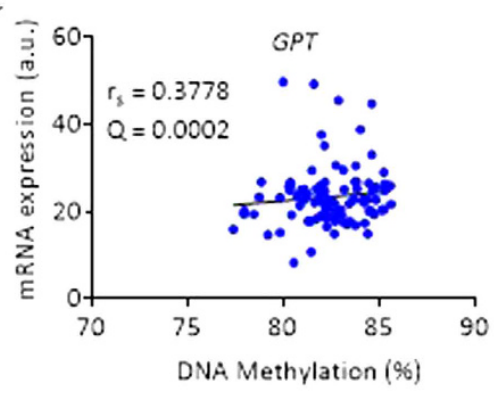

B

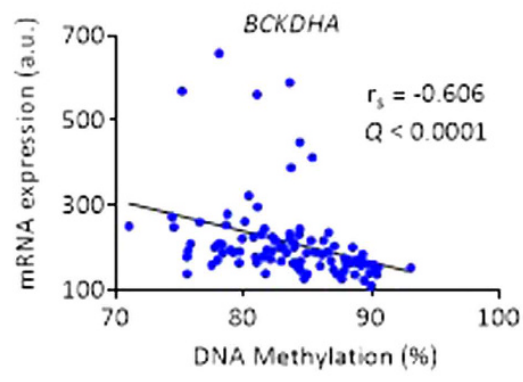

D

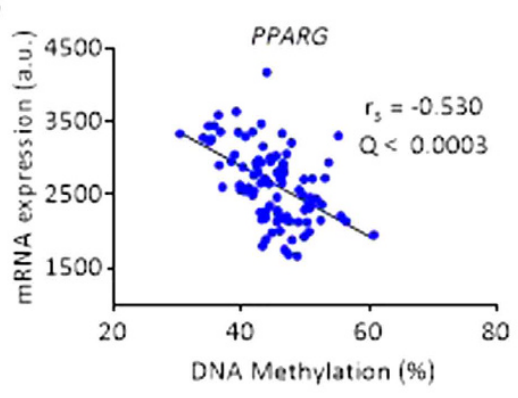

Figure 4. Representative illustrations of correlations of gene expression with DNA methylation in adipose tissue from cohort 1. Expression $C D 74$ correlated positively with DNA methylation (A);BCKDHA correlated negatively with DNA methylation (B); GPT correlated positively with DNA methylation (C); and PPARG correlated negatively with DNA methylation (D). Spearman rank correlation with FDR corrections.

the expression of secreted frizzled-related protein-2, a Wnt5a antagonist. Targeting the Wnt/ $\beta$-catenin signaling pathway may have clinical implications in the context of common complications of atherosclerosis, T2D and obesity $^{64,65}$. Of interest, we found DNA methylation activated gene sets in the Wnt/ $\beta$-catenin signaling pathway in adipose tissue in the present study. Previous studies have implicated that Wnt signaling activation of $\beta$-catenin, a negative co-activator, and PPARG might dysregulate adipogenesis ${ }^{66}$. PPARG gene expression was positively associated with insulin sensitivity (GDR) and negatively associated with adipocyte size and testosterone, although these associations did not survive after adjustment for BMI. Further, many of the significant canonical pathways included gene sets with differentially methylated genes or with differential gene expression in human adipose tissue that are similar to pathways detected in adipose tissue of prenatal androgenized rhesus monkeys ${ }^{67}$ (e.g., the Wnt $/ \beta$-catenin and TGF- $\beta$ signaling pathways). These findings support the hypothesis that maternal androgen excess causes an unfavorable intrauterine environment and leads to epigenetic changes that contribute to the development of insulin resistance and altered molecular signaling pathways in adipose tissue of women with PCOS.

SVEP1, another gene associated with $\mathrm{T} 2 \mathrm{D}^{28}$, encodes a cell-adhesion molecule expressed by cells related to skeletal tissues. Hypermethylation of SVEP1 decreases its expression ${ }^{68}$, consistent with our finding of decreased mRNA expression and increased DNA methylation of SVEP1 in adipose tissue in women with PCOS; however, SVEP1 mRNA expression correlated negatively with adipocyte volume after adjustment for BMI.

$I R S 1$, a substrate of insulin receptor tyrosine kinase, have a central role in the insulin stimulated signaling and is a candidate gene of $\mathrm{T} 2 \mathrm{D}^{69}$. We were not able to replicate the expression found in cohort 1 . Instead there was a trend towards decreased mRNA expression of IRS1 was $(P=0.058)$ in cohort 2 . Of note, cohort 1 includes normal, overweight and obese subjects and all these analyses were corrected for BMI. The decrease in IRS1 mRNA expression may reflect that the replication cohort was overweight - obese. This is further supported by the fact that when dividing cohort 1 into lean $v s$ overweight - obese, the IRS 1 mRNA expression was lower among the overweight - obese women (mean \pm SD) $318.2 \pm 113.4$ vs $232.4 \pm 71.8, P<0.001$ ). This phenomenon has previously been demonstrated in e.g. Pima Indians there IRS1 mRNA expression is approximately 1.8 fold lower in adipocytes from obese subjects compared with normal weight subjects ${ }^{70}$. The results in the present study is in agreement with a recent study demonstrating that the insulin signaling pathway in subcutaneous adipose tissues is not the major contributor to the pathogenesis of $\mathrm{PCOS}^{71}$.

DNA methylation is important in many biological processes, such as regulation of transcription, genomic imprinting, chromatin structure, and silencing of repetitive DNA elements ${ }^{72}$. Abnormal DNA methylation is common in human cancers and contributes to tumorigenesis ${ }^{73}$. DNA methylation in mammalian cells is carried out by DNMTs. DNMT1-associated protein (DMAP1) has an intrinsic repressive activity and helps maintain DNA methylation in a heritable manner ${ }^{74}$. Interestingly, a large number of DNMTs were differentially methylated in adipose tissue form women with PCOS. These finding further support the hypothesis that maternal androgen excess $^{75}$ can induce epigenetic changes ${ }^{57}$. 
A

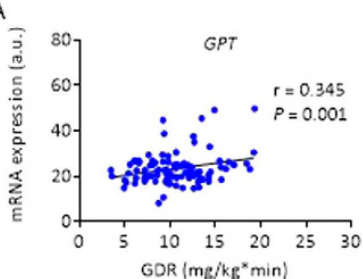

B

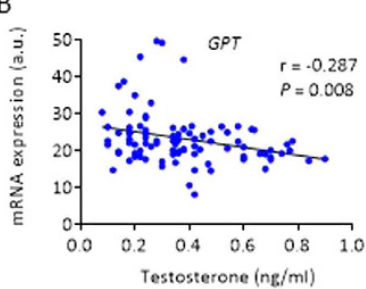

C

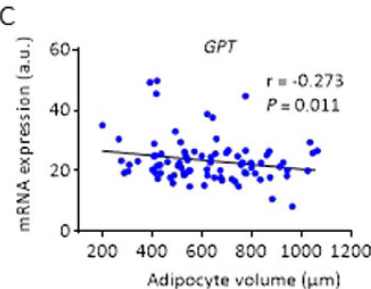

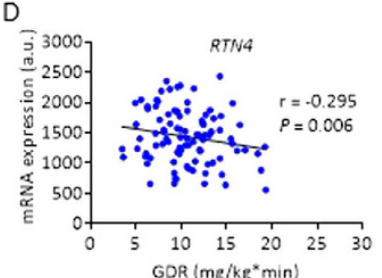

$\mathrm{E}$
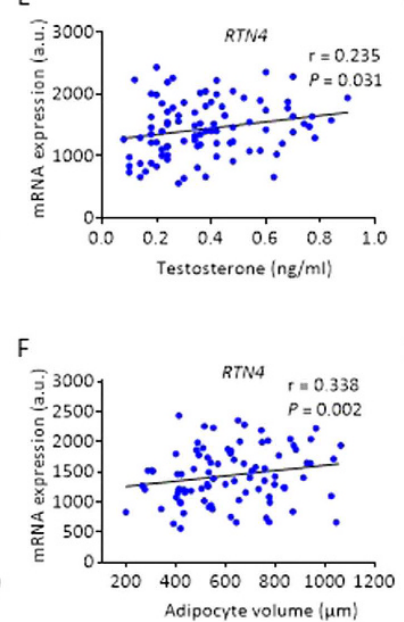
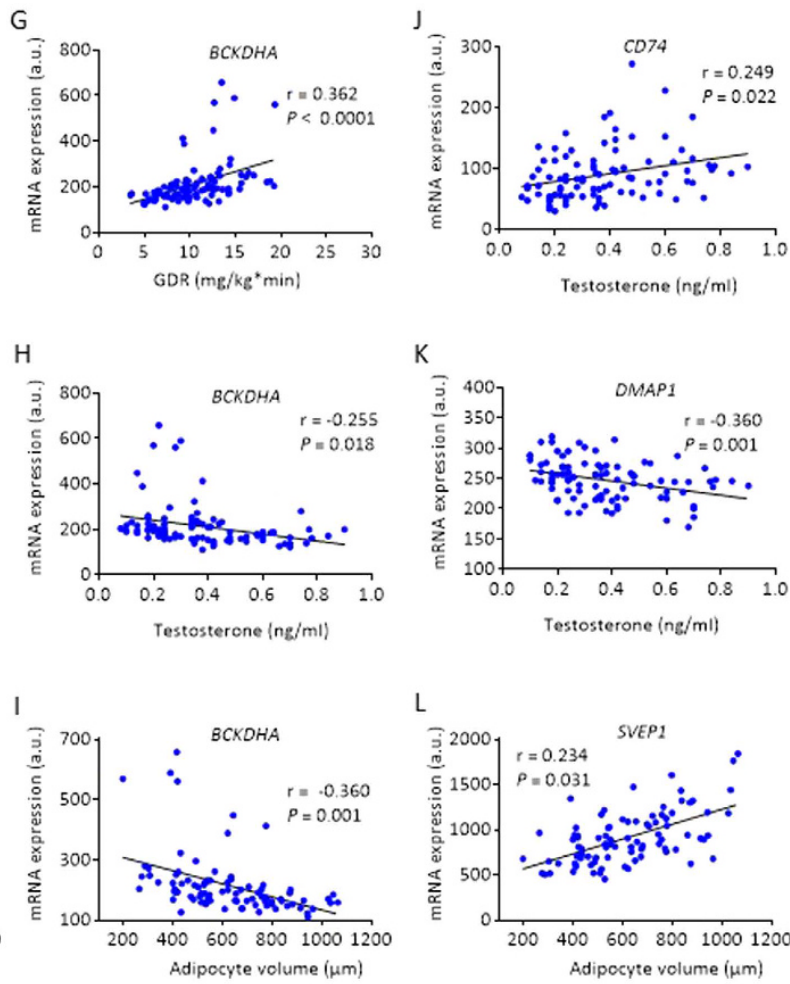

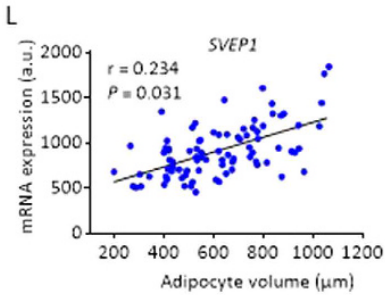

Figure 5. Correlations of GDR, adipocyte size, and circulating testosterone level with gene expression in adipose tissue from cohort 1. Expression of GPT correlated positively with GDR (A), negatively with circulating testosterone (B), and with adipocyte volume (C); RTN4 correlated negatively with GDR (D), positively with testosterone $(\mathbf{E})$, and with adipocyte volume $(\mathbf{F}) ; B C K D H A$ correlated positively with GDR $(\mathbf{G})$, negatively with circulating testosterone $(\mathbf{H})$, and with adipocyte volume $(\mathbf{I})$; $C D 74$ correlated positively with circulating testosterone $(\mathbf{J}) ; D M P A 1$ correlated negatively with circulating testosterone $(\mathbf{K})$; and SVEP1 correlated positively with adipocyte volume (L). Pearson's partial correlation.

Adipose tissue is composed of many cell types, and changes in cell composition may have contributed to the differences in gene expression and DNA methylation we observed. Previously, we showed that there is no major impact of cellular composition or inflammatory response on observed associations in DNA methylation in adipose tissue and BMI and $\mathrm{HbAl} \mathrm{c}^{53}$. Although adipocyte isolation per se may affect gene expression and DNA methylation, it would be of interest to investigate genome-wide gene expression and DNA methylation in adipocytes from different fat depots. Future studies should also investigate the role of additional epigenetic mechanisms, including miRNAs and histone modifications which may be of importance in PCOS. Analyzes in the present study is limited to subcutaneous adipose tissue. Visceral fat accumulation is an independent risk factor of $\mathrm{T} 2 \mathrm{D}^{76}$. The visceral fat depot is drained by the portal venous system leading to a direct supply of free fatty acids, and may therefore be considered as more metabolic active ${ }^{77}$. However, different genes may have different functions in the two depots; e.g. PPARG have a twofold higher mRNA expression in subcutaneous than in visceral adipose tissue in lean/overweight subjects ${ }^{78}$. In contrast, in obese subjects, mRNA expression of PPARG was similar in the two depots. Of note, in the present study including both lean and overweight/obese women with PCOS displayed lower PPARG expression independent of BMI. Women with PCOS display a "male like" fat distribution with abdominal (subcutaneous and visceral) fat accumulation ${ }^{79}$. Few studies have investigated differences between gene expression in subcutaneous and visceral fat depots in women with PCOS with no major differences ${ }^{15,80}$. Another limitation is the cross sectional design and that we have only 30 controls compared with 64 cases, although to date this study is the largest investigating genome wide DNA methylation and expression in women with PCOS.

In conclusion, we identified a large number of genes and pathways that are affected in adipose tissue from women with PCOS. We also identified specific DNA methylation pathways that may affect mRNA expression. Together, these novel findings show that women with PCOS have multiple transcriptional and epigenetic changes in adipose tissue that are relevant for development of the disease.

\section{Material and Methods}

Study participants. Cohort 1 consisted of 64 women with PCOS and 30 controls who had successful subcutaneous adipose tissue biopsies and were previously described in detail ${ }^{9}$. Case-control cohort 2 consisted of 21 women with PCOS and 21 controls matched pairwise for age, weight, and BMI were included for replication of the findings in cohort 1. 
All women provided oral and written informed consent. The two studies were conducted at the Sahlgrenska Academy, University of Gothenburg and at Sahlgrenska University Hospital, Gothenburg, Sweden, in accordance with the Declaration of Helsinki and were approved by the Regional Ethical Review Board of the University of Gothenburg. After all relevant clinical information was obtained, samples were coded and anonymized.

Subject recruitment, exclusion and inclusion criteria are described in detail in Supplementary Material and Methods.

Clinical examination. Body weight and height were measured in subjects wearing light clothing; body mass index was calculated as $\mathrm{kg} / \mathrm{m}^{2}$. Waist circumference was measured between the lower rib and iliac crest. In controls, blood samples were obtained in the morning after an overnight fast during the early follicular phase (days 1-7 of the menstrual cycle) to match the hormonal milieu of PCOS subjects and to avoid the preovulatory estrogen rise. Fasting blood samples were collected independently of cycle day in women with PCOS as the majority had oligo/anovulation. Subcutaneous abdominal adipose tissue biopsies were obtained under local anesthesia and immediately isolated for measurement of adipocyte size $e^{9}$ or snap frozen in liquid nitrogen and stored at $-80^{\circ} \mathrm{C}$. Whole-body glucose homeostasis was measured by euglycemic hyperinsulinemic clamp with calculation of GDR, and by calculation of HOMA-IR and HOMA-B ${ }^{9}$.

Biochemical analyses. Plasma glucose was measured at $37^{\circ} \mathrm{C}$ with an enzymatic photometric method (Roche Diagnostics, Mannheim, Germany) in cohort 1 and by One Touch Ultra2 (LifeScan) in cohort 2. Serum insulin was measured with an immunometric two-step sandwich method and chemiluminescence (Advia Centaur Insulin ReadyPack; Bayer HealthCare). Estrogen and testosterone were measured by gas chromatography-tandem mass spectrometry, and SHBG was analyzed by chemiluminescent microparticle immunoassay as described ${ }^{10,81}$.

RNA and DNA Extraction from Adipose Tissue. For gene expression array studies, RNA was extracted with the RNeasy Lipid tissue Mini Kit (Qiagen). For methylation array studies, DNA was isolated with the QIAamp DNA Mini Kit (Qiagen). Nucleic acid concentrations and purity were estimated with a NanoDrop spectrophotometer (Thermo Scientific). DNA integrity was also checked by gel electrophoresis, and RNA quality was determined with an automated electrophoresis station (Experion, Bio-Rad).

Expression Arrays and quantitative real-time PCR. To assess the global mRNA expression profile in adipose tissue, we analyzed isolated mRNA with high abundance with microarray HumanHT-12 v4 Expression BeadChip (Illumina). cRNA synthesis, including biotin labeling, was carried out using Illumina TotalPrep RNA Amplification Kit (Life Technologies \& Invitrogen) according to manufacturer's recommendations. Biotin-cRNA complex was then fragmented and hybridized to the probes on the Illumina BeadChip array. Probes were hybridized and stained with streptavidin-Cy3 before visualization with Illuminas HiScan fluorescence camera. The Oligo package from Bioconductor was used to compute Robust Multichip Average expression measures ${ }^{82}$.

In cohort 2, quantitative real-time PCR analysis of selected genes (Table S4) was validated with custom TaqMan gene expression array micro fluid cards (Life Technologies) i.e. the replication cohort. Samples were run in duplicate; the amount of cDNA in each loading port was equivalent to $100 \mathrm{ng}$ of mRNA. The arrays were run according to the manufacturer's protocol with a QuantStudio 7 Flex Real-time PCR System and QuantStudio 7 software (Life Technologies). Candidate reference genes (GAPDH, LRP10, and CLN3) were validated with NormFinder algorithm; from this algorithm, the combination of LRP10 and CLN3 was used as the reference control. Gene expression values were calculated with the $\Delta \Delta \mathrm{C}_{\mathrm{q}}$ method (i.e., $\mathrm{RQ}=2^{-\Delta \Delta \mathrm{Cq}}$ ).

Immunoblot Analysis. To analyze protein expression in adipose tissue homogenates we used antibodies against CYP1B1 (AV51761, Sigma-Aldrich, Stockholm Sweden) and PPARG (ab191407, Abcam, Cambride, UK). Briefly, samples were centrifuged at $13,000 \mathrm{~g}$ for $10 \mathrm{~min}$ at $4{ }^{\circ} \mathrm{C}$ and protein concentration was determined with a Direct Detect ${ }^{\mathrm{TM}}$ spectrometer (Millipore, Billerica, USA). $50 \mu \mathrm{g}$ of total protein was loaded on Criterion $^{\mathrm{TM}}$ TGX (Tris-Glycine eXtended) Stain-Free ${ }^{\mathrm{TM}}$ precast gels (Bio-Rad) and transferred to nitrocellulose midi-membrane in the Trans-Blot ${ }^{\circledR}$ Turbo $^{\mathrm{TM}}$ Transfer System (Bio-Rad). GAPDH was used as a loading control and for normalization.

DNA Methylation Arrays. Genome-wide DNA methylation in adipose tissue was analyzed with Illumina Infinium HumanMethylation450k array BeadChips. The array contains 485,577 cytosine probes covering 21,231 (99\%) RefSeq genes ${ }^{83}$. A Zymo Methylation Kit (D5001-D5002, Zymo Research) was used to convert genomic DNA to the bisulfite-modified DNA. Briefly, gDNA (500 ng) of high quality was fragmented and hybridized on the BeadChip, and the intensities of the signal were measured with a HiScanQ scanner (Illumina). The methylation values for each $\mathrm{CpG}$ site are presented as a $\beta$-value ranging from 0 (unmethylated) to $100 \%$ (completely methylated).

The bioinformatics analyses were performed as described ${ }^{21,53}$. In brief, Y chromosome probes, rs-probe, and probes with average detection $p$-value $>0.01$ were removed. After quality control and filtering, methylation data was obtained in $483,317 \mathrm{CpG}$ sites. Beta-values were converted to $\mathrm{M}$-values $(\mathrm{M}=\log 2(\beta /(1-\beta)$, which were used for all data analyses. Data were then quantile normalized and batch corrected with COMBAT ${ }^{84}$. A linear regression model was used to identify differences in DNA methylation between women with PCOS and controls. To improve interpretation, after all the preprocessing steps, data were reconverted to beta-values, which are presented in tables and figures.

Ingenuity pathway analysis. Ingenuity Pathway Analysis (Qiagen) was used for core analyses of data from the gene expression array and DNA methylation array so we could interpret the outcome and make predictions 
based on known libraries. Fold change and $Q$ - and $P$-values were calculated before data entry, and thereafter uploaded for Ingenuity Pathway Analysis. $Q<0.05$ was used as the cut-off for gene expression and $P<0.05$ for DNA methylation. Top canonical pathways are based on the $P$-value overlap of genes in our dataset with molecules in the canonical pathway.

Statistics. Differences between clinical characteristics in cohort 1 were based on ANCOVA with adjustment for age and BMI. Fisher's permutation test was used for comparisons of clinical characteristics in cohort 2; no adjustments for age and BMI were needed, as the cases and controls were matched for age, weight, and BMI. DNA methylation differences between cases and controls in cohort 1 were based on linear regression including batch, age and BMI. The Mann-Whitney U test was used for expression analyses. FDR was used to correct for multiple testing in the analyses of gene and methylation arrays. The chi-square test was used to calculate whether the differentially methylated sites were more than the expected number by chance. Also, differentially expressed genes with a $Q<0.05$ were merged with corresponding probes in the methylation data. For these analyses, a CpG site was annotated to the nearest gene. Correlations in women with PCOS plus controls (cohort 1) between DNA methylation and gene expression of selected genes and GDR and testosterone were analyzed by Spearman's correlation with correction for multiple testing. Data are presented as mean $\pm \mathrm{SD}$.

\section{References}

1. Norman, R. J., Dewailly, D., Legro, R. S. \& Hickey, T. E. Polycystic ovary syndrome. Lancet 370, 685-697 (2007).

2. Diamanti-Kandarakis, E. \& Dunaif, A. Insulin resistance and the polycystic ovary syndrome revisited: an update on mechanisms and implications. Endocr Rev 33, 981-1030 (2012).

3. Lim, S. S., Davies, M. J., Norman, R. J. \& Moran, L. J. Overweight, obesity and central obesity in women with polycystic ovary syndrome: a systematic review and meta-analysis. Hum Reprod Update 18, 618-637 (2012).

4. Hickey, T. E., Legro, R. S. \& Norman, R. J. Epigenetic modification of the X chromosome influences susceptibility to polycystic ovary syndrome. J Clin Endocrinol Metab 91, 2789-2791 (2006).

5. Moran, L. J., Noakes, M., Clifton, P. M., Norman, R. J. \& Fenech, M. F. Genome instability is increased in lymphocytes of women with polycystic ovary syndrome and is correlated with insulin resistance. Mutat Res 639, 55-63 (2008).

6. Xu, N., Azziz, R. \& Goodarzi, M. O. Epigenetics in polycystic ovary syndrome: A pilot study of global DNA methylation. Fertil Steril 94, 781-783 (2010)

7. Manneras-Holm, L. et al. Coagulation and fibrinolytic disturbances in women with polycystic ovary syndrome. J Clin Endocrinol Metab 96, 1068-1076 (2011).

8. Manneras-Holm, L., Benrick, A. \& Stener-Victorin, E. Gene expression in subcutaneous adipose tissue differs in women with polycystic ovary syndrome and controls matched pair-wise for age, body weight, and body mass index. Adipocyte 3, 190-196 (2014).

9. Manneras-Holm, L. et al. Adipose tissue has aberrant morphology and function in PCOS: enlarged adipocytes and low serum adiponectin, but not circulating sex steroids, are strongly associated with insulin resistance. J Clin Endocrinol Metab 96, E304-311 (2011).

10. Stener-Victorin, E. et al. Are there any sensitive and specific sex steroid markers for polycystic ovary syndrome? J Clin Endocrinol Metab 95, 810-819 (2010)

11. Ciaraldi, T. P., Aroda, V., Mudaliar, S., Chang, R. J. \& Henry, R. R. Polycystic ovary syndrome is associated with tissue-specific differences in insulin resistance. J Clin Endocrinol Metab 94, 157-163 (2009).

12. Ek, I., Arner, P., Bergqvist, A., Carlstrom, K. \& Wahrenberg, H. Impaired adipocyte lipolysis in nonobese women with the polycystic ovary syndrome: a possible link to insulin resistance? J Clin Endocrinol Metab 82, 1147-1153 (1997).

13. Jones, M. R. et al. Steroidogenic regulatory factor FOS is underexpressed in polycystic ovary syndrome (PCOS) adipose tissue and genetically associated with PCOS susceptibility. J Clin Endocrinol Metab 97, E1750-1757 (2012).

14. Corton, M. et al. Differential Gene Expression Profile in Omental Adipose Tissue in Women with Polycystic Ovary Syndrome. J Clin Endocrinol Metab 92, 328-337 (2007).

15. Carmina, E. et al. Subcutaneous and omental fat expression of adiponectin and leptin in women with polycystic ovary syndrome. Fertil Steril 9, 642-648 (2008).

16. Tan, B. K. et al. Omentin-1, a novel adipokine, is decreased in overweight insulin-resistant women with polycystic ovary syndrome: ex vivo and in vivo regulation of omentin-1 by insulin and glucose. Diabetes 57, 801-808 (2008).

17. Tan, B. K. et al. Upregulation of adiponectin receptor 1 and 2 mRNA and protein in adipose tissue and adipocytes in insulinresistant women with polycystic ovary syndrome. Diabetologia 49, 2723-2728 (2006).

18. Chazenbalk, G. et al. Abnormal expression of genes involved in inflammation, lipid metabolism, and Wnt signaling in the adipose tissue of polycystic ovary syndrome. J Clin Endocrinol Metab 97, E765-770 (2012).

19. Abbott, D. H., Barnett, D. K., Bruns, C. M. \& Dumesic, D. A. Androgen excess fetal programming of female reproduction: a developmental aetiology for polycystic ovary syndrome? Hum Reprod Update 11, 357-374 (2005).

20. Waterland, R. A. Is epigenetics an important link between early life events and adult disease? Hormone research 71 Suppl 1, 13-16 (2009).

21. Nilsson, E. et al. Altered DNA methylation and differential expression of genes influencing metabolism and inflammation in adipose tissue from subjects with type 2 diabetes. Diabetes 63, 2962-2976 (2014).

22. Wang, X. X. et al. Genome-wide DNA methylation and gene expression patterns provide insight into polycystic ovary syndrome development. Oncotarget 5, 6603-6610 (2014).

23. Yu, Y. Y. et al. Genome-wide screen of ovary-specific DNA methylation in polycystic ovary syndrome. Fertil Steril S0015-0282(15)00249-6 (2015).

24. Qu, F. et al. A molecular mechanism underlying ovarian dysfunction of polycystic ovary syndrome: hyperandrogenism induces epigenetic alterations in the granulosa cells. J Mol Med (Berl) 90, 911-923 (2012).

25. Jones, M. R. et al. Systems Genetics Reveals the Functional Context of PCOS Loci and Identifies Genetic and Molecular Mechanisms of Disease Heterogeneity. PLoS genetics 11, e1005455 (2015).

26. Shi, Y. et al. Genome-wide association study identifies eight new risk loci for polycystic ovary syndrome. Nat Genet 44, 1020-1025 (2012).

27. Replication, D. I. G. et al. Genome-wide trans-ancestry meta-analysis provides insight into the genetic architecture of type 2 diabetes susceptibility. Nat Genet 46, 234-244 (2014).

28. Pasquale, L. R. et al. Exploring genome-wide - dietary heme iron intake interactions and the risk of type 2 diabetes. Frontiers in genetics 4, 7 (2013).

29. Voight, B. F. et al. Twelve type 2 diabetes susceptibility loci identified through large-scale association analysis. Nat Genet 42, 579-589 (2010). 
30. Cotsapas, C. et al. Common body mass index-associated variants confer risk of extreme obesity. Human molecular genetics 18, 3502-3507 (2009).

31. Wheeler, E. et al. Genome-wide SNP and CNV analysis identifies common and low-frequency variants associated with severe earlyonset obesity. Nat Genet 45, 513-517 (2013).

32. Ellero, S. et al. Xenobiotic-metabolizing cytochromes p450 in human white adipose tissue: expression and induction. Drug Metab Dispos 38, 679-686 (2010).

33. Inoue, K., Matsumoto, M., Miyoshi, Y. \& Kobayashi, Y. Elevated liver enzymes in women with a family history of diabetes. Diabetes Res Clin Pract 79, e4-7 (2008).

34. Kamei, Y. et al. Increased expression of DNA methyltransferase 3a in obese adipose tissue: studies with transgenic mice. Obesity (Silver Spring) 18, 314-321 (2010)

35. Yoon, J. C. et al. Wnt signaling regulates mitochondrial physiology and insulin sensitivity. Genes Dev 24, 1507-1518 (2010).

36. Le Lay, S., Simard, G., Martinez, M. C. \& Andriantsitohaina, R. Oxidative stress and metabolic pathologies: from an adipocentric point of view. Oxid Med Cell Longev 2014, 908539 (2014).

37. Yagishita, Y. et al. Nrf2 protects pancreatic beta-cells from oxidative and nitrosative stress in diabetic model mice. Diabetes 63, 605-618 (2014).

38. Ma, R. C. et al. Genome-wide association study in a Chinese population identifies a susceptibility locus for type 2 diabetes at $7 \mathrm{q} 32$ near PAX4. Diabetologia 56, 1291-1305 (2013).

39. Palmer, N. D. et al. A genome-wide association search for type 2 diabetes genes in African Americans. PLoS One 7, e29202 (2012).

40. Cho, Y. S. et al. Meta-analysis of genome-wide association studies identifies eight new loci for type 2 diabetes in east Asians. Nat Genet 44, 67-72 (2012).

41. Kim, H. J. et al. Combined linkage and association analyses identify a novel locus for obesity near PROX1 in Asians. Obesity (Silver Spring) 21, 2405-2412 (2013).

42. Cheng, J. et al. Molecular mechanism for USP7-mediated DNMT1 stabilization by acetylation. Nature communications $\mathbf{6}, 7023$ (2015).

43. Kim, B. S., Pallua, N., Bernhagen, J. \& Bucala, R. The macrophage migration inhibitory factor protein superfamily in obesity and wound repair. Experimental \& molecular medicine 47, e161 (2015).

44. Lynch, C. J. \& Adams, S. H. Branched-chain amino acids in metabolic signalling and insulin resistance. Nat Rev Endocrinol 10, 723-736 (2014).

45. Hall, E. et al. Effects of palmitate on genome-wide mRNA expression and DNA methylation patterns in human pancreatic islets. BMC Med 12, 103 (2014).

46. Kim, B. S. et al. Macrophage Migration Inhibitory Factor in Acute Adipose Tissue Inflammation. PLoS One 10, e0137366 (2015).

47. Liu, X. et al. CYP1B1 deficiency ameliorates obesity and glucose intolerance induced by high fat diet in adult C57BL/6J mice. American journal of translational research 7, 761-771 (2015).

48. Yang, B. T. et al. Increased DNA methylation and decreased expression of PDX-1 in pancreatic islets from patients with type 2 diabetes. Mol Endocrinol 26, 1203-1212 (2012).

49. Nitert, M. D. et al. Impact of an Exercise Intervention on DNA Methylation in Skeletal Muscle From First-Degree Relatives of Patients With Type 2 Diabetes. Diabetes 61, 3322-3332 (2012).

50. Jones, P. A. Functions of DNA methylation: islands, start sites, gene bodies and beyond. Nat Rev Genet 13, 484-492 (2012).

51. Ling, C. et al. Genetic and epigenetic factors are associated with expression of respiratory chain component NDUFB6 in human skeletal muscle. J Clin Invest 117, 3427-3435 (2007).

52. Olsson, A. H. et al. Genome-wide associations between genetic and epigenetic variation influence mRNA expression and insulin secretion in human pancreatic islets. PLoS genetics 10, e1004735 (2014).

53. Ronn, T. et al. Impact of age, BMI and HbAlc levels on the genome-wide DNA methylation and mRNA expression patterns in human adipose tissue and identification of epigenetic biomarkers in blood. Human molecular genetics 24, 3792-3813 (2015).

54. Dayeh, T. et al. Genome-wide DNA methylation analysis of human pancreatic islets from type 2 diabetic and non-diabetic donors identifies candidate genes that influence insulin secretion. PLoS genetics 10, e1004160 (2014).

55. Dayeh, T. A. et al. Identification of CpG-SNPs associated with type 2 diabetes and differential DNA methylation in human pancreatic islets. Diabetologia 56, 1036-1046 (2013).

56. Kaminsky, Z. A. et al. DNA methylation profiles in monozygotic and dizygotic twins. Nat Genet 41, 240-245 (2009).

57. Ollikainen, M. et al. DNA methylation analysis of multiple tissues from newborn twins reveals both genetic and intrauterine components to variation in the human neonatal epigenome. Human molecular genetics 19, 4176-4188 (2010).

58. Vink, J. M., Sadrzadeh, S., Lambalk, C. B. \& Boomsma, D. I. Heritability of polycystic ovary syndrome in a Dutch twin-family study. JClin Endocrinol Metab 91, 2100-2104 (2006).

59. Chen, Z. J. et al. Genome-wide association study identifies susceptibility loci for polycystic ovary syndrome on chromosome 2p16.3, 2p21 and 9q33.3. Nat Genet 43, 55-59 (2011).

60. Taniguchi Ishikawa, E. et al. Klf5 controls bone marrow homing of stem cells and progenitors through Rab5-mediated beta1/beta2integrin trafficking. Nature Communications 4, 1660 (2013).

61. Hayes, G. M. et al. Genomewide Association of Polycystic Ovary Syndrome Implicates Alterations in Gonadotropin Secretion in European Ancestry Populations. Nature Communication 6, 7502 (2015).

62. Lehrke, M. \& Lazar, M. A. The many faces of PPARgamma. Cell 123, 993-999 (2005).

63. Hughes, T. S. et al. An alternate binding site for PPARgamma ligands. Nature Communications 5, 3571 (2014).

64. Acosta, J. R. et al. Increased fat cell size: a major phenotype of subcutaneous white adipose tissue in non-obese individuals with type 2 diabetes. Diabetologia, doi: 10.1007/s00125-015-3810-6 (2015).

65. Woldt, E. et al. The nuclear hormone receptor PPARgamma counteracts vascular calcification by inhibiting Wnt5a signalling in vascular smooth muscle cells. Nature Communications 3, 1077 (2012).

66. Hammarstedt, A. et al. WISP2 regulates preadipocyte commitment and PPARgamma activation by BMP4. Proc Natl Acad Sci USA 110, 2563-2568 (2013).

67. Xu, N. et al. Epigenetic mechanism underlying the development of polycystic ovary syndrome (PCOS)-like phenotypes in prenatally androgenized rhesus monkeys. PLoS One 6, e27286 (2011).

68. Glait-Santar, C. \& Benayahu, D. SVEP1 promoter regulation by methylation of CpG sites. Gene 490, 6-14 (2011).

69. Kwon, H., Lee, J., Jeong, K., Jang, D. \& Pak, Y. Fatty acylated caveolin-2 is a substrate of insulin receptor tyrosine kinase for insulin receptor substrate-1-directed signaling activation. Biochim Biophys Acta 1853, 1022-1034 (2015).

70. Kovacs, P. et al. The role of insulin receptor substrate-1 gene (IRS1) in type 2 diabetes in Pima Indians. Diabetes 52, 3005-3009 (2003).

71. Xu, N. et al. Comprehensive assessment of expression of insulin signaling pathway components in subcutaneous adipose tissue of women with and without polycystic ovary syndrome. J Clin Transl Endocrinol 2, 99-104 (2015).

72. Smith, Z. D. \& Meissner, A. DNA methylation: roles in mammalian development. Nat Rev Genet 14, 204-220 (2013).

73. Baylin, S. B. \& Jones, P. A. A decade of exploring the cancer epigenome - biological and translational implications. Nature reviews. Cancer 11, 726-734 (2011).

74. Rountree, M. R., Bachman, K. E. \& Baylin, S. B. DNMT1 binds HDAC2 and a new co-repressor, DMAP1, to form a complex at replication foci. Nat Genet 25, 269-277 (2000). 
75. Maliqueo, M. et al. Placental steroidogenesis in pregnant women with polycystic ovary syndrome. Eur J Obstet Gynecol Reprod Biol 166, 151-155 (2013).

76. Ohlson, L. O. et al. The influence of body fat distribution on the incidence of diabetes mellitus. 13.5 years of follow-up of the participants in the study of men born in 1913. Diabetes 34, 1055-1058 (1985).

77. Bjorntorp, P. "Portal" adipose tissue as a generator of risk factors for cardiovascular disease and diabetes. Arteriosclerosis 10, 493-496 (1990).

78. Lefebvre, A. M. et al. Depot-specific differences in adipose tissue gene expression in lean and obese subjects. Diabetes 47, 98-103 (1998).

79. Oh, J. Y., Sung, Y. A. \& Lee, H. J. The Visceral Adiposity Index as a Predictor of Insulin Resistance in Young Women with Polycystic Ovary Syndrome. Obesity 21, 1690-1694 (2013).

80. Martinez-Garcia, M. A. et al. Evidence for masculinization of adipokine gene expression in visceral and subcutaneous adipose tissue of obese women with polycystic ovary syndrome (PCOS). J Clin Endocrinol Metab 98, E388-396 (2013).

81. Nilsson, M. E. et al. Measurement of a comprehensive sex steroid profile in rodent serum by high-sensitive gas chromatographytandem mass spectrometry. Endocrinology, en20141890 (2015).

82. Bolstad, B. M., Irizarry, R. A., Astrand, M. \& Speed, T. P. A comparison of normalization methods for high density oligonucleotide array data based on variance and bias. Bioinformatics 19, 185-193 (2003)

83. Bibikova, M. et al. High density DNA methylation array with single CpG site resolution. Genomics 98, 288-295 (2011).

84. Johnson, W. E., Li, C. \& Rabinovic, A. Adjusting batch effects in microarray expression data using empirical Bayes methods. Biostatistics 8, 118-127 (2007).

\section{Acknowledgements}

The work was supported by the Swedish Medical Research Council Project No. 2014-2775 (ESV) and 2013-3018 (CL), Jane and Dan Olsson Foundation (ESV), Wilhelm and Martina Lundgrens's Science Fund (ESV), Hjalmar Svensson Foundation (ESV), Adlerbert Research Foundation (ESV), and the Swedish federal government under the LUA/ALF agreement ALFGBG-429501 (ESV) and ALF Lund 2014-354 (CL), Novo Nordisk Foundation (ESV CL), Swedish Diabetes Foundation (CL), and Påhlsson Foundation (CL), and Swedish Pharmaceutical Society (MK). We thank the Genomics Core Facility at the Sahlgrenska Academy, University of Gothenburg, for the use of technical equipment and support.

\section{Author Contributions}

A.B., C.L. and E.S.-V. conceived and designed the study. M.K., A.B., R.F., A.P., M.M., C.J.B. and A.S. performed experiments and statistical analyses. M.K., R.F., E.N., A.B., C.O., C.L. and E.S.-V. contributed to the analysis and interpretation of data. M.K. and E.S.-V. wrote the manuscript. All of the authors revised critically and approved the manuscript.

\section{Additional Information}

Supplementary information accompanies this paper at http://www.nature.com/srep

Competing financial interests: The authors declare no competing financial interests.

How to cite this article: Kokosar, M. et al. Epigenetic and Transcriptional Alterations in Human Adipose Tissue of Polycystic Ovary Syndrome. Sci. Rep. 6, 22883; doi: 10.1038/srep22883 (2016).

This work is licensed under a Creative Commons Attribution 4.0 International License. The images or other third party material in this article are included in the article's Creative Commons license, unless indicated otherwise in the credit line; if the material is not included under the Creative Commons license, users will need to obtain permission from the license holder to reproduce the material. To view a copy of this license, visit http://creativecommons.org/licenses/by/4.0/ 


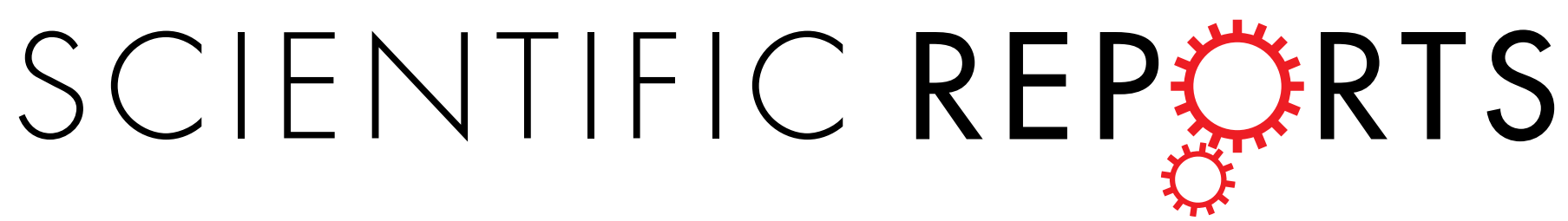

\section{OPEN Erratum: Epigenetic and} Transcriptional Alterations in Human Adipose Tissue of Polycystic
Ovary Syndrome

Milana Kokosar, Anna Benrick, Alexander Perfilyev, Romina Fornes, Emma Nilsson, Manuel Maliqueo, Carl Johan Behre, Antonina Sazonova, Claes Ohlsson, Charlotte Ling \& Elisabet Stener-Victorin

Scientific Reports 6:22883; doi: 10.1038/srep22883; published online 15 March 2016; updated 09 May 2016

This Article contains errors.

In Table 3, the text in the first row 'Down-regulated genes' was incorrectly given as 'Up-regulated genes'.

In addition, Fig. 2E was incorrectly labeled as Fig. 2ES. The correct Fig. 2E appears below as Fig. 1.

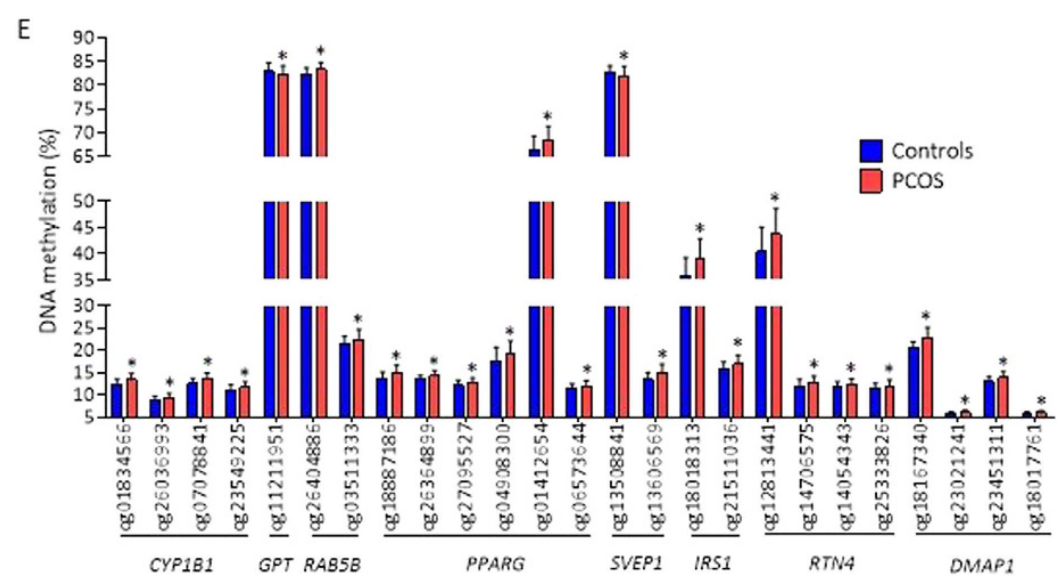

Figure 1.

(i) This work is licensed under a Creative Commons Attribution 4.0 International License. The images or other third party material in this article are included in the article's Creative Commons license, unless indicated otherwise in the credit line; if the material is not included under the Creative Commons license, users will need to obtain permission from the license holder to reproduce the material. To view a copy of this license, visit http://creativecommons.org/licenses/by/4.0/ 